\title{
18. GEOCHEMICAL HISTORY OF POST-MIDDLE JURASSIC SEDIMENTATION IN THE SOUTHWESTERN ATLANTIC, DEEP SEA DRILLING PROJECT LEG 71: Ba, Sr, AND MAJOR COMPONENTS1
}

\author{
I. M. Varentsov, Geological Institute of the U.S.S.R. Academy of Sciences, Moscow, U.S.S.R.
}

\begin{abstract}
The geochemistry of the major components plus $\mathrm{Ba}$ and $\mathrm{Sr}$ are interpreted in the context of data on lithology and mineralogy and of the available geological information. The role of biogenic, clastic, authigenic, and hydrothermal constituents in the history of post-Middle Jurassic sedimentation is quantitatively estimated. The results of factor analysis of the chemical components and peculiarities of the distribution of average accumulation rates are considered. Five main stages in the geochemical history of sedimentation are distinguished:

1) Late-Middle Jurassic to Early Cretaceous, 160.0-106.0 Ma: Sedimentation in a shallow-water basin.

2) Middle/early Albian to middle Maestrichtian, 106.0(?)-66.4 Ma: Sedimentation in an extending and deepening open oceanic basin.

3) Late Maestrichtian to late-middle Eocene, 66.4-57.0(?) Ma: An erosional hiatus of almost global extent.

4) Late/middle Eocene to early Miocene, 57.0-15.0 Ma: Widespread development of erosional hiatuses with accumulation of residual products and intense sedimentation of biogenic $\mathrm{CaCO}_{3}$ and $\mathrm{SiO}_{2}$.

5) Neogene to Quaternary, 15.0 Ma to present: Opening of the Drake Passage at the Paleogene/Neogene boundary, followed by deepening of the basin, northward invasion of Antarctic water masses rich in nutrient components, and a depression of the CCD.

In the Quaternary the Polar Front retreated somewhat, followed by decreased rates of biogenic sedimentation and increased accumulation of glacial products.
\end{abstract}

\section{INTRODUCTION}

The main objectives of DSDP Leg 71 were to study the evolution of sedimentation and paleoceanographical environments in the southwestern Atlantic during the post-Middle Jurassic (Ludwig et al., 1980) (see Fig. 1). The geochemical study of the major components and of the trace elements $\mathrm{Ba}$ and $\mathrm{Sr}$ in the context of mineralogical, lithological, and geological data permit a quantitative estimation of the effects of biogenic, clastic, authigenic, and hydrothermal components on sedimentation and lithogenesis, and of their variations in time and space.

\section{MATERIALS AND METHODS}

This work is based on the results of lithologic-geochemical studies of core samples from DSDP Leg 71, received from V. A. Krasheninnikov; the work was carried out at the Geological Institute of the U.S.S.R. Academy of Sciences. The lithologic-mineral composition of the sediments is described in other chapters (e.g., Varentsov et al., this volume). All chemically analyzed samples were also studied as thin sections under a microscope. The mineral varieties were studied by X-ray diffraction using slides prepared either from a natural sediment or its size fractions, particularly the fraction $<0.001 \mathrm{~mm}$. Chemical components were identified at the laboratories of the Institute of Geochemistry of the Siberian Branch of the U.S.S.R. Academy of Sciences, Irkutsk, under the direction of Dr. V. P. Afonin, by means of $\mathrm{X}$-ray fluorescence spectroscopy, using international reference standards. In addition, control identifications were made by wet chemistry methods.

Analytical data were processed by computer $(\mathrm{EC}-1022)$ in the laboratory of mathematical methods of the Geological Institute of the U.S.S.R. Academy of Sciences (D. A. Kazimirov) using the factor

\footnotetext{
${ }^{1}$ Ludwig, W. J., Krasheninnikov, V. A., et al., Init. Repts. DSDP, 71: Washington (U.S. Govt. Printing Office).
}

analysis program (R-, Q-mode; Davis, 1973; Herman, 1967). The specific features of paragenetic assemblages of the factor clusters determined by factor analysis of oceanic sediments have been considered by Lein $n$ and Stakes, 1979; Varentsov, 1980; and Varentsov et al., 1981. The identification of the assemblages was based on grouping the components with significant factor loadings of one sign. For a better representation of relationships between the components of an assemblage, each chemical component is characterized by the factor loading value, given in parentheses, for the factor with which it is most closely connected. The better expressed values of factor loadings were obtained after transformation of the data by the rotation method (Davis, 1973). Calculation of the average rates of accumulation for chemical components are considered elsewhere (Varentsov et al., 1981). Sediment densities were derived from measurements made aboard ship (see site chapters, this volume). The Mesozoic and Cenozoic geochronology is that adopted by the shipboard scientists (Berggren, 1973; Geological Society of London, 1964; Hardenbol and Berggren, 1978; Larson and Hilde, 1975; Van Eysinga, 1975).

\section{PARAGENETIC ASSEMBLAGES OF COMPONENTS (Table 1)}

\author{
Assemblage IA(+) \\ $\mathrm{Na}_{2} \mathrm{O}(0.23)-\mathrm{MgO}(0.14)-\mathrm{Al}_{2} \mathrm{O}_{3}(0.94)-\mathrm{SiO}_{2}(0.87)-$ \\ $\mathrm{K}_{2} \mathrm{O}(0.95)-\mathrm{TiO}_{2}(0.94)-\mathrm{Fe}_{2} \mathrm{O}_{3}(0.89)$
}

The components of this factor group compared with the real mineral composition of sediments shows that this assemblage is predominantly represented by mixedlayer clay components: mica/smectite. (More detailed data on the distribution of these clay minerals are given in Varentsov et al., this volume.)

Distribution of this assemblage vertically and laterally through the sequence (Table 2) distinctly indicates its dual nature:

1) Relatively high factor scores (exceeding 0.5 ) occur in geochronological intervals with increased accumula- 


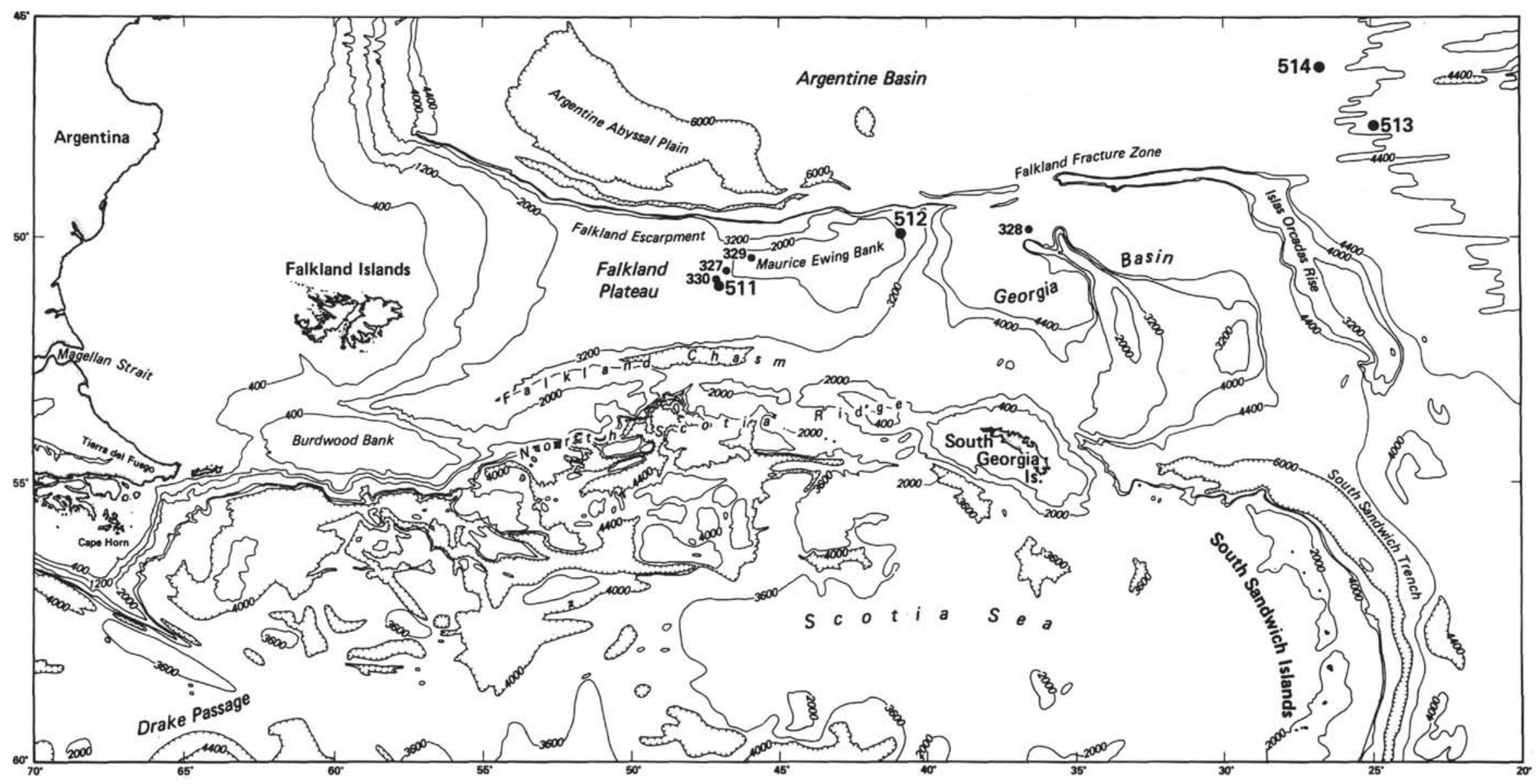

Figure 1. Location of Leg 71 sites. 
Table 1. Results of factor analysis (R-mode) for chemical components (wt.\%) in Cenozoic and Mesozoic sediments, DSDP Leg 71.

\begin{tabular}{|c|c|c|c|c|c|c|}
\hline \multirow[b]{3}{*}{ Component } & \multicolumn{6}{|c|}{ Factor Loadings (after rotation) } \\
\hline & \multicolumn{2}{|c|}{ I } & \multicolumn{2}{|c|}{ II } & \multicolumn{2}{|c|}{ III } \\
\hline & $\mathbf{I a}(+)$ & $\mathrm{IB}(-)$ & $\operatorname{IIA}(+)$ & $\mathrm{IIB}(-)$ & $\operatorname{IIIA(+)}$ & $\operatorname{IIIB}(-)$ \\
\hline $\mathrm{Na}_{2} \mathrm{O}$ & 0.23 & & 0.46 & & & -0.69 \\
\hline $\mathrm{MgO}$ & 0.14 & & 0.13 & & & -0.58 \\
\hline $\mathrm{Al}_{2} \mathrm{O}_{3}$ & 0.94 & & & -0.18 & & -0.10 \\
\hline $\mathrm{SiO}_{2}$ & 0.87 & & 0.29 & & & -0.14 \\
\hline $\mathrm{P}_{2} \mathrm{O}_{5}$ & 0.02 & & & -0.79 & & -0.03 \\
\hline $\mathrm{K}_{2} \mathrm{O}$ & 0.95 & & & -0.12 & & -0.002 \\
\hline $\mathrm{CaO}$ & & -0.82 & & -0.41 & 0.20 & \\
\hline $\mathrm{TiO}_{2}$ & 0.94 & & & -0.11 & & -0.23 \\
\hline MnŎ & & -0.03 & & -0.63 & 0.23 & \\
\hline $\mathrm{Fe}_{2} \mathrm{O}_{3}$ & 0.89 & & & -0.20 & & -0.18 \\
\hline LOI & & -0.90 & & -0.28 & 0.21 & \\
\hline $\mathrm{Sr}$ & & -0.87 & & -0.28 & 0.01 & \\
\hline $\mathrm{Ba}$ & 0.05 & & & -0.09 & & -0.84 \\
\hline \multicolumn{3}{|c|}{ Dispersion input (\%) 53.29} & \multicolumn{2}{|c|}{15.01} & \multicolumn{2}{|c|}{9.08} \\
\hline \multicolumn{2}{|c|}{ Total dispersion $(\%)$} & 3.29 & \multicolumn{2}{|c|}{68.30} & \multicolumn{2}{|c|}{77.38} \\
\hline
\end{tabular}

Table 2. Factor assemblage IA(+): Average factor scores.

\begin{tabular}{|c|c|c|c|c|}
\hline Age & Site 511 & Site 512 & Site 514 & Site 513 \\
\hline $\left.\begin{array}{l}\text { Holocene } \\
\text { Pleistocene }\end{array}\right\}$ & $?$ & 1.01 & 0.61 & 0.32 \\
\hline \multicolumn{5}{|l|}{ Pliocene } \\
\hline $\begin{array}{l}\text { late } \\
\text { early }\end{array}$ & $\begin{array}{c}\text { Hiatus } \\
?\end{array}$ & Hiatus $\}$ & $\begin{array}{l}0.55,0.55, \\
0.47\end{array}$ & $\begin{array}{l}0.46 \\
0.61\end{array}$ \\
\hline \multicolumn{5}{|l|}{ Miocene } \\
\hline $\begin{array}{l}\text { late } \\
\text { middle }\end{array}$ & & \}- & & $\begin{array}{l}0.57 \\
\text { Hiatus }\end{array}$ \\
\hline early & Hiatus & & & 0.46 \\
\hline \multicolumn{5}{|l|}{ Oligocene } \\
\hline $\begin{array}{l}\text { late } \\
\text { early }\end{array}$ & $0.30\}$ & Hiatus & & 0.04 \\
\hline \multicolumn{5}{|l|}{ Eocene } \\
\hline late & - & & & Basalt \\
\hline $\begin{array}{l}\text { middle } \\
\text { early }\end{array}$ & Hiatus & - & & \\
\hline \multicolumn{5}{|l|}{ Paleocene } \\
\hline $\begin{array}{l}\text { late } \\
\text { early }\end{array}$ & 0.67 & & & \\
\hline $\begin{array}{l}\text { Maestrichtian } \\
\text { late }\end{array}$ & Hiatus & & & \\
\hline middle & 0.09 & & & \\
\hline $\left.\begin{array}{c}\text { early } \\
\text { Campanian }\end{array}\right\}$ & 0.78 & & & \\
\hline $\left.\begin{array}{l}\text { Santonian } \\
\text { Coniacian }\end{array}\right\}$ & 0.46 & & & \\
\hline $\begin{array}{l}\text { Coniacian } \\
\text { Turonian }\end{array}$ & 1.15 & & & \\
\hline \multicolumn{5}{|l|}{ Cenomanian } \\
\hline $\begin{array}{l}\text { Albian } \\
\text { late }\end{array}$ & Hiatus & & & \\
\hline middle & 0.14 & & & \\
\hline early & 0.61 & & & \\
\hline $\left.\begin{array}{l}\text { Aptian } \\
\text { Barremian }\end{array}\right\}$ & 0.54 & & & \\
\hline Hauterivian & & & & \\
\hline $\begin{array}{l}\text { Valanginian } \\
\text { Berriasian } \\
\text { Portlandian }\end{array}$ & Hiatus & & & \\
\hline $\left.\begin{array}{l}\text { Kimmeridgian } \\
\text { Oxfordian }\end{array}\right\}$ & 0.86 & & & \\
\hline
\end{tabular}

Note: For the components of factor assemblage IA $(+)$, see Table 1. tion of clastic materials: for Hole 511 (Falkland Plateau) in the Upper Jurassic and lower Maestrichtian to Campanian sediments; for Hole 512, in Holocene-Pleistocene sediments; for Hole 514, in Pliocene-Holocene.

2) High factor scores are typical of deposits at the boundaries of large-scale erosional hiatuses. (The authigenic nature of hydromica components formed at the hiatus boundaries is considered in detail in Varentsov et al., this volume.)

\section{Assemblage IB(-). \\ $\mathrm{CaO}(-0.82)-\mathrm{LOI}(-0.90)-\mathrm{Sr}(-0.87)$}

The set of components convincingly points to the biogenic carbonate composition of this assemblage, where $\mathrm{Sr}$ plays the role of an isomorphous admixture.

Figure 2 shows that considerable amounts of biogenic carbonate sediments in the South-Western Atlantic accumulated in the middle Maestrichtian (Hole 511) and continued till the end of the early-late Miocene as a function of the paleoceanographic environment of the water masses. At the same time a correlation among intervals with high value scores for this assemblage enables us to note the migration of the Polar Front during the Cenozoic, when carbonate sedimentation at the site was succeeded by intense accumulation of siliceous sediments.

\section{Assemblage IIA(+) \\ $\mathrm{Na}_{2} \mathrm{O}(0.46)-\mathrm{MgO}(0.13)-\mathrm{SiO}_{2}(0.29)$}

This assemblage is represented mostly by biogenic silica associated with the major cations of sea water, $\mathrm{Na}$ and $\mathrm{Mg}$. High factor scores of the assemblage are typical chiefly of Neogene sediments (Fig. 3), when cold Antarctic water masses invaded the southwestern Atlantic after opening of the Drake Passage and sharply increased the carbonate compensation depth (CCD). Residual siliceous accumulations were subordinate and developed predominantly at the boundaries, above hiatuses, i.e., in the late Eocene of the Falkland Plateau, Hole 511.

\section{Assemblage IIB( - )}

$\mathrm{Al}_{2} \mathrm{O}_{3}(-0.18)-\mathrm{P}_{2} \mathrm{O}_{5}(-0.79)-\mathrm{K}_{2} \mathrm{O}(-0.12)-\mathrm{CaO}$ $(-0.41)-\mathrm{TiO}_{2}(-0.11)-\mathrm{MnO}(-0.63)-\mathrm{Fe}_{2} \mathrm{O}_{3}(-0.20)-$ LOI $(-0.28)-\operatorname{Sr}(-0.28)$

The assemblage is represented mainly by residual and, to a lesser extent, authigenic matter composed of a mixture of $\mathrm{Ca}, \mathrm{Al}$-phosphates, mica minerals, and relict carbonates. The highest factor scores of this group occur in the basal deposits at the boundaries of large erosional hiatuses (Table 3). However, the averaged factor scores calculated for relatively large geochronological subdivisions level out considerably the pronounced readings for the residual accumulations (lag deposits) which occur at the zone of erosional contact. This can be illustrated by figures showing the distribution of factor scores for this cluster, e.g., in the zone of the middleearly Albian (Unit 5) and at the Turonian/late Cenomanian erosional contact of Hole 511, the Falkland Plateau (Fig. 4A). Figure 4A also shows the average factor scores of this assemblage for particular stratigraphic subdivisions. Similar relationships are also observed in the zones 


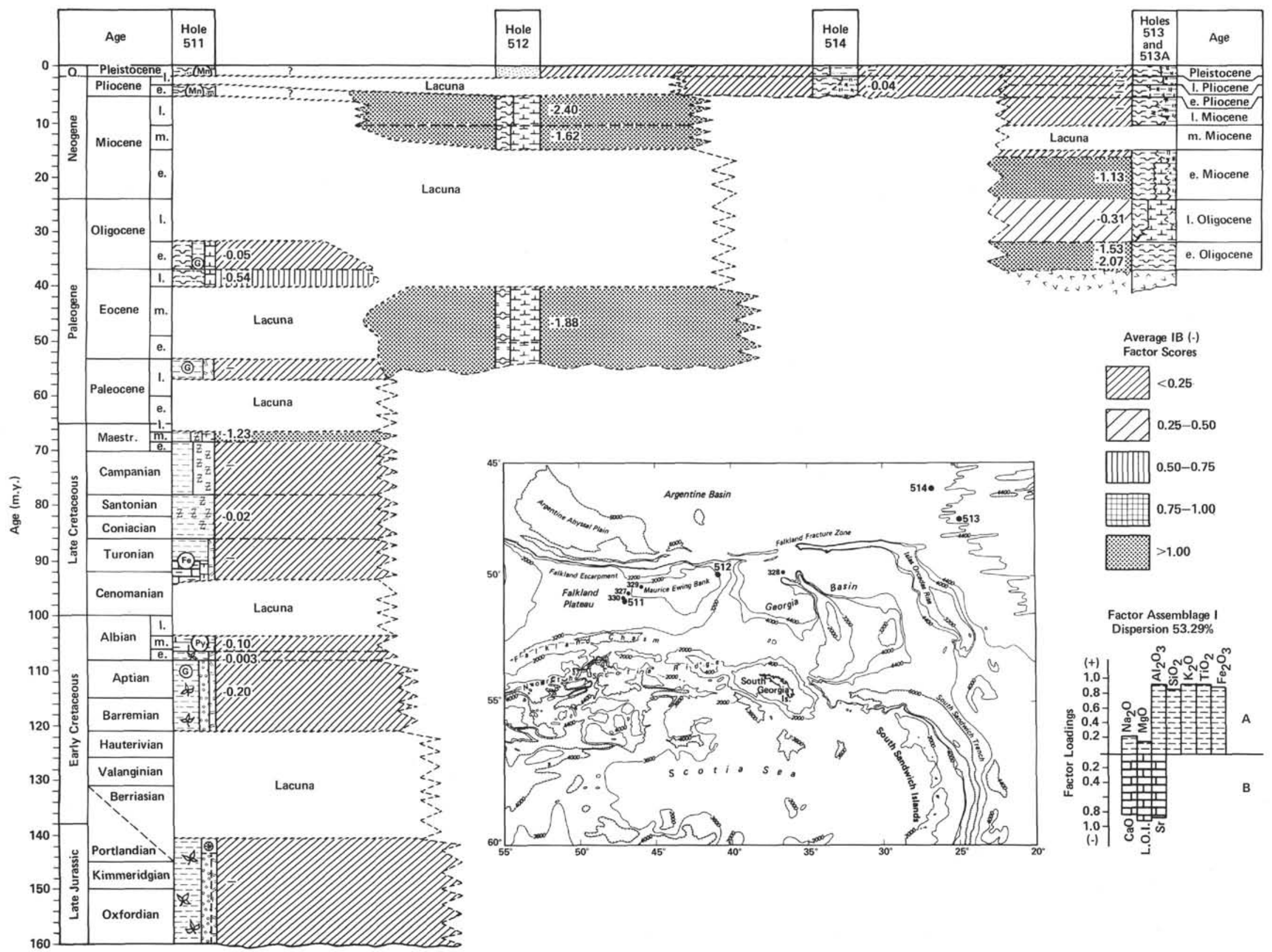

Figure 2. Average factor scores distribution of the IB(-) chemical components assemblage in post-Middle Jurassic sediments in the southwestern Atlantic, Leg 71 . The assemblage is represented by calcium carbonate with $\mathrm{Sr}$ admixture (see Table 1). 


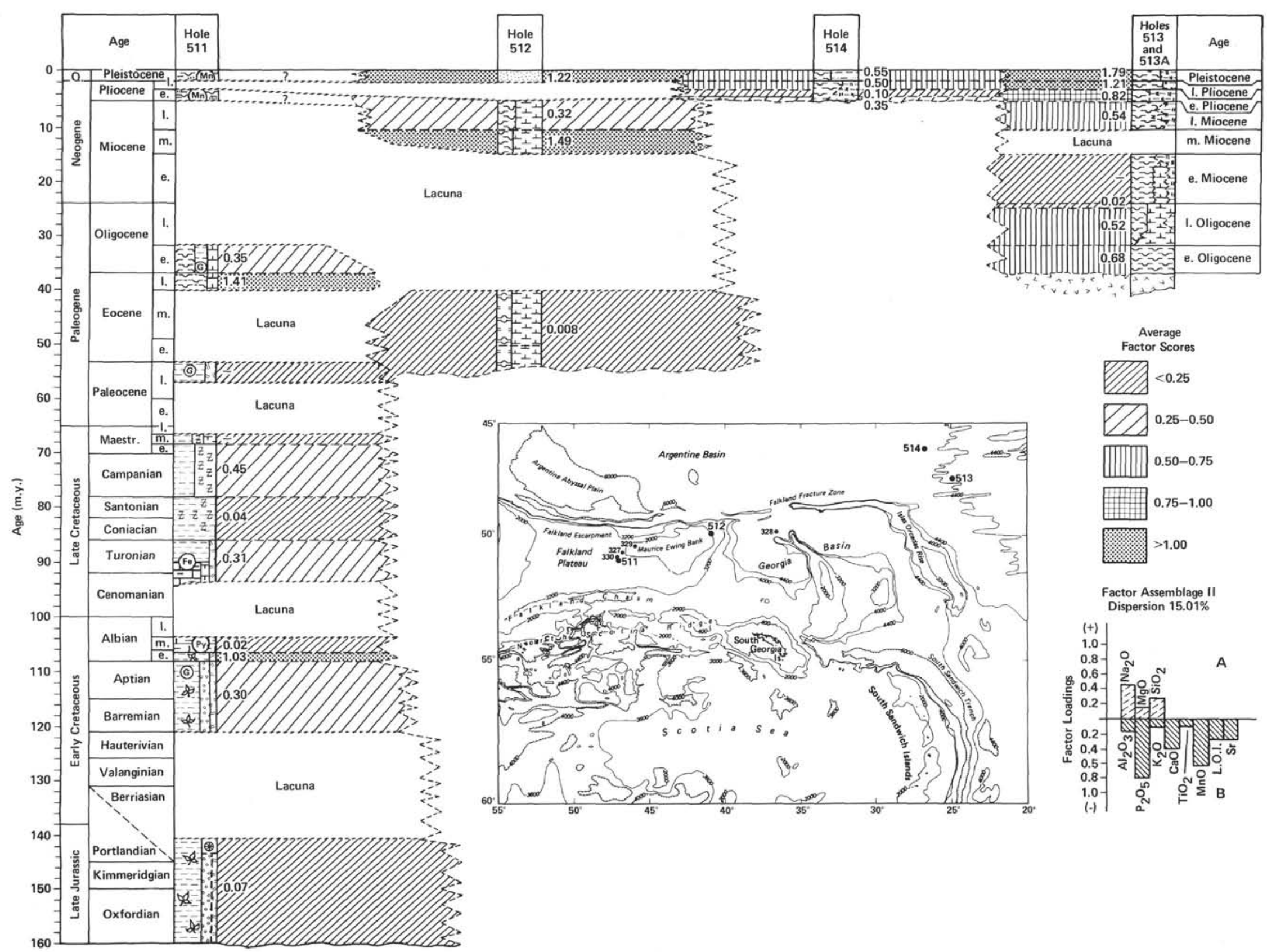

Figure 3. Average factor scores distribution of the IIA(+) chemical components assemblage in post-Middle Jurassic sediments in the southwestern Atlantic, Leg 71 . The assemblage is represented mainly by the compounds of free $\mathrm{SiO}_{2}$ with $\mathrm{Na}$ and $\mathrm{Mg}$ admixtures (see Table 1). 
Table 3. Factor assemblage IIB(-): Average factor scores.

\begin{tabular}{|c|c|c|c|c|}
\hline Age & Site 511 & Site 512 & Site 514 & Site 513 \\
\hline $\left.\begin{array}{l}\text { Holocene } \\
\text { Pleistocene }\end{array}\right\}$ & ? & - & -0.04 & - \\
\hline $\begin{array}{l}\text { Pliocene } \\
\text { late } \\
\text { early }\end{array}$ & $\begin{array}{c}\text { Hiatus } \\
?\end{array}$ & Hiatus $\}$ & $\begin{array}{l}-0.02,-0.08, \\
-0.21\end{array}$ & $\overline{-}$ \\
\hline Miocene & & & & \\
\hline $\begin{array}{l}\text { late } \\
\text { middle } \\
\text { early }\end{array}$ & Hiatus & $=$ & & $\begin{array}{l}-0.02 \\
\text { Hiatus } \\
-1.27\end{array}$ \\
\hline Oligocene & & & & \\
\hline $\begin{array}{l}\text { late } \\
\text { early }\end{array}$ & $-0.03\}$ & Hiatus & & $\begin{array}{l}-0.56,-0.34 \\
-0.09,-0.22\end{array}$ \\
\hline Eocene & & & & \\
\hline late & - & & & Basalt \\
\hline $\begin{array}{l}\text { middle } \\
\text { early }\end{array}$ & Hiatus & -0.45 & & \\
\hline Paleocene & & & & \\
\hline $\begin{array}{l}\text { late } \\
\text { early }\end{array}$ & -2.06 & & & \\
\hline $\begin{array}{l}\text { Maestrichtian } \\
\text { late }\end{array}$ & Hiatus & & & \\
\hline middle & -1.09 & & & \\
\hline $\left.\begin{array}{c}\text { early } \\
\text { Campanian }\end{array}\right\}$ & -0.64 & & & \\
\hline $\left.\begin{array}{l}\text { Santonian } \\
\text { Coniacian }\end{array}\right\}$ & -0.77 & & & \\
\hline Turonian & -0.35 & & & \\
\hline Cenomanian & & & & \\
\hline $\begin{array}{l}\text { Albian } \\
\text { late }\end{array}$ & Hiatus & & & \\
\hline $\begin{array}{l}\text { middle } \\
\text { early }\end{array}$ & $\begin{array}{l}-1.29 \\
-0.55\end{array}$ & & & \\
\hline $\left.\begin{array}{l}\text { Aptian } \\
\text { Barremian } \\
\text { Hauterivian }\end{array}\right\}$ & -0.44 & & & \\
\hline $\begin{array}{l}\text { Hauterivian } \\
\text { Valanginian } \\
\text { Berriasian } \\
\text { Portlandian }\end{array}$ & Hiatus & & & \\
\hline $\begin{array}{l}\text { Kimmeridgian } \\
\text { Oxfordian }\end{array}$ & -0.37 & & & \\
\hline
\end{tabular}

Note: For the components of factor assemblage IIB(-), see Table 1.

of large erosional hiatuses, such as at the boundaries of the Mesozoic/Cenozoic, Hole 511 (Fig. 4B), middle Eocene/middle Miocene, Hole 512 (Fig. 4C), and early/late Miocene, Holes 513 and 513A (Fig. 4D) boundaries. The residual nature of the products accumulated in the zones of erosional contacts considerably favors authigenic, hydrogenic mineral formation, and particularly the processes of formation of hydroxide phases of manganese and iron.

\section{Assemblage IIIA(+)}

$\mathrm{CaO}(0.20)-\mathrm{MnO}(0.23)-\mathrm{LOI}(0.21)$

This set of components and their correlation with the chemical and mineralogical data for the sediments show that this assemblage is represented by postsedimentation phases of isomorphic manganocalcite molecules.

This cluster of components is most distinctly expressed in the Upper Jurassic to middle-lower Albian deposits of the Falkland Plateau, Hole 511 (Table 4), where it is represented by fine spherolites $(0.007-0.02 \mathrm{~mm})$, products of epigenetic alteration of volcaniclastics, and disseminated patches of manganese hydroxides. A rather distinct correlation was observed between factor scores and $\mathrm{Mn} / \mathrm{Fe}$ values. However, the factor scores are not absolute values. This can be explained by the discrepancy between them and the contents of $\mathrm{MnCO}_{3}$ and $\mathrm{Mn}$ / $\mathrm{Fe}$ observed in a number of cases. In other sequences of the southwestern Atlantic (Holes 512 and 513), the mineralogical representation of this assemblage is not so distinct.

$$
\begin{aligned}
& \text { Assemblage IIIB( }-) \\
& \quad \mathrm{Na}_{2} \mathrm{O}(-0.69)-\mathrm{MgO}(-0.58)-\mathrm{Al}_{2} \mathrm{O}_{3}(-0.10)-\mathrm{SiO}_{2} \\
& (-0.14)-\mathrm{TiO}_{2}(-0.23)-\mathrm{Fe}_{2} \mathrm{O}_{3}(-0.18)-\mathrm{Ba}(-0.84)
\end{aligned}
$$

The highest values of factor loadings in this assemblage were observed for $\mathrm{Ba}-\mathrm{Na}-\mathrm{Mg}$. The complex of components and the distribution of the assemblage suggest that this cluster is represented predominantly by barite with an accompanying admixture of finely dispersed clay particles (Appendices A and B, this chapter). Intense accumulations of barite manifested in relatively high factor scores $(>0.75)$ (Fig. 5) were observed in those geochronological intervals with intense biological productivity: the early Maestrichtian to Campanian and the late Paleocene of Hole 511; the Middle Eocene of Hole 512; the Pliocene-Pleistocene of Hole 514; and intervals with high biological productivity related to the migration of the Polar Front during the Miocene to early Pliocene in Hole 513.

\section{GEOCHEMICAL ASPECTS OF SEDIMENTATION}

\section{$\mathrm{Al}$ and $\mathrm{Ti}$ (accumulation of clastic components, Tables 5 and 6)}

$\mathrm{Al}$ and $\mathrm{Ti}$ belong to a group of major chemical components which provide an opportunity to estimate quantitatively the clastic contribution to sedimentation (Boström et al., 1973; Chester, 1965; Chester and Aston, 1976; Goldberg and Arrhenius, 1958; Leinen and Stakes, 1979). The data of Turekian and Wedepohl (1961) show that the $\mathrm{Ti} / \mathrm{Al}$ ratio in Ca-granites is 0.041 , in basalts, 0.177 , and in clay sediments, $0.0547-0.0575$. Goldberg and Arrhenius (1958), Chester (1965), and Chester and Aston (1976) have shown that the major amount of $\mathrm{Ti}$ in oceanic sediments is associated with basalt volcaniclastics and their alteration products. This conclusion, made for the first time by Goldberg and Arrhenius (1958), is based mainly on studies of deep-sea (pelagic, abyssal) sediments of the Pacific Ocean in which the products of basaltoid volcanism predominate. This enables us to assume that in sediments where $\mathrm{Ti} / \mathrm{Al}>0.055$, the products of basaltoid volcanism play a rather definite role. The distribution of average $\mathrm{Ti} / \mathrm{Al}$ values throughout the sequences (Table 5) reflects two features well expressed in the clastic components:

1) In upper Mesozoic deposits (Upper Jurassic-Cretaceous) the $\mathrm{Ti} / \mathrm{Al}$ values do not exceed 0.050 and possibly reflect an important role played by products derived from the disintegration of granitoid, predominantly continental rocks. Cenozoic sediments have a $\mathrm{Ti} / \mathrm{Al}$ ratio of $>0.050$.

2) The following trends are noted in $\mathrm{Ti} / \mathrm{Al}$ values in the Cenozoic sediments: (a) the ratio increases with age (the highest values of $\mathrm{Ti} / \mathrm{Al}$ are observed in Pleistocene sediments; (b) values are rather high in the area of the 

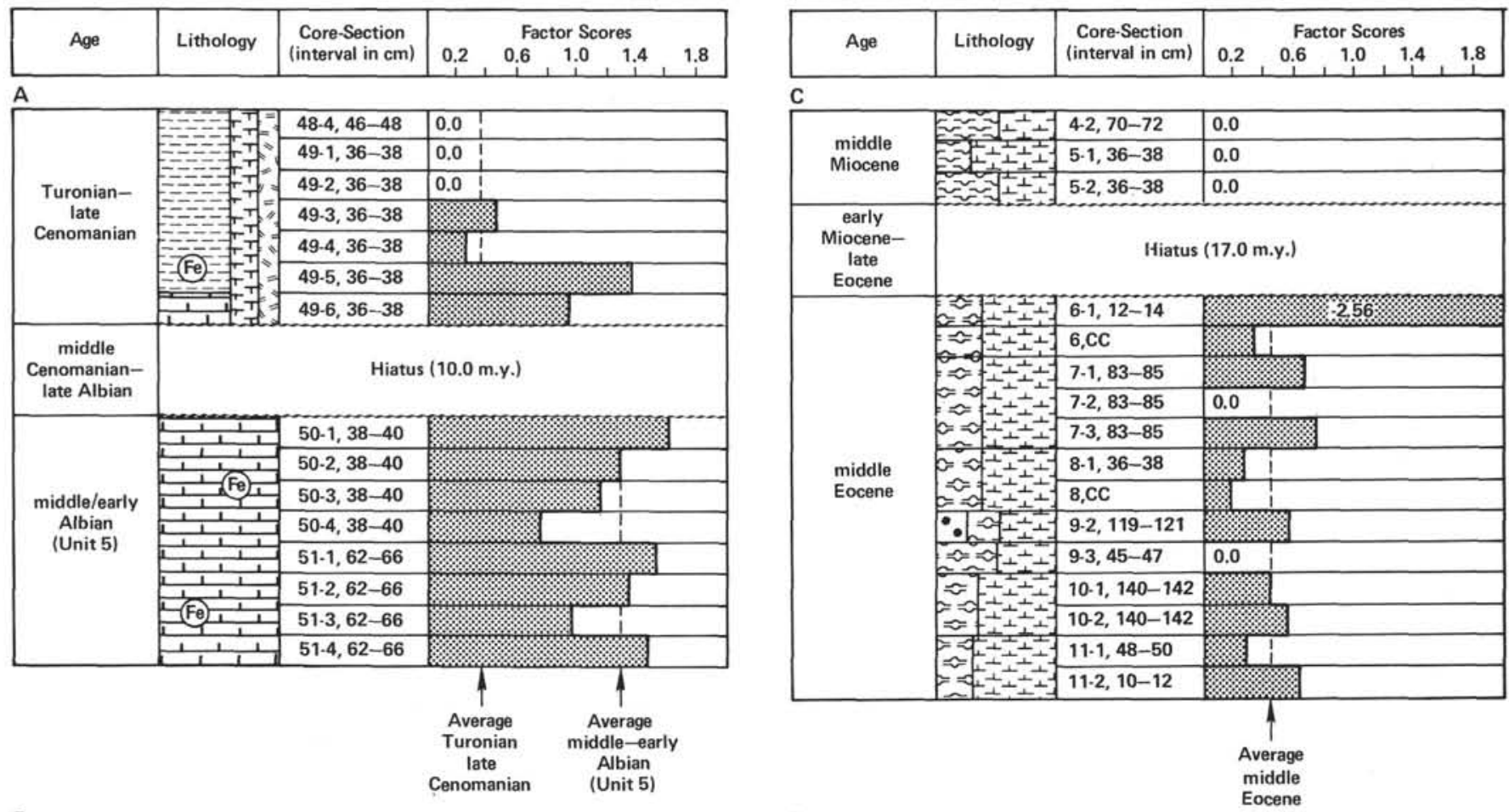

B
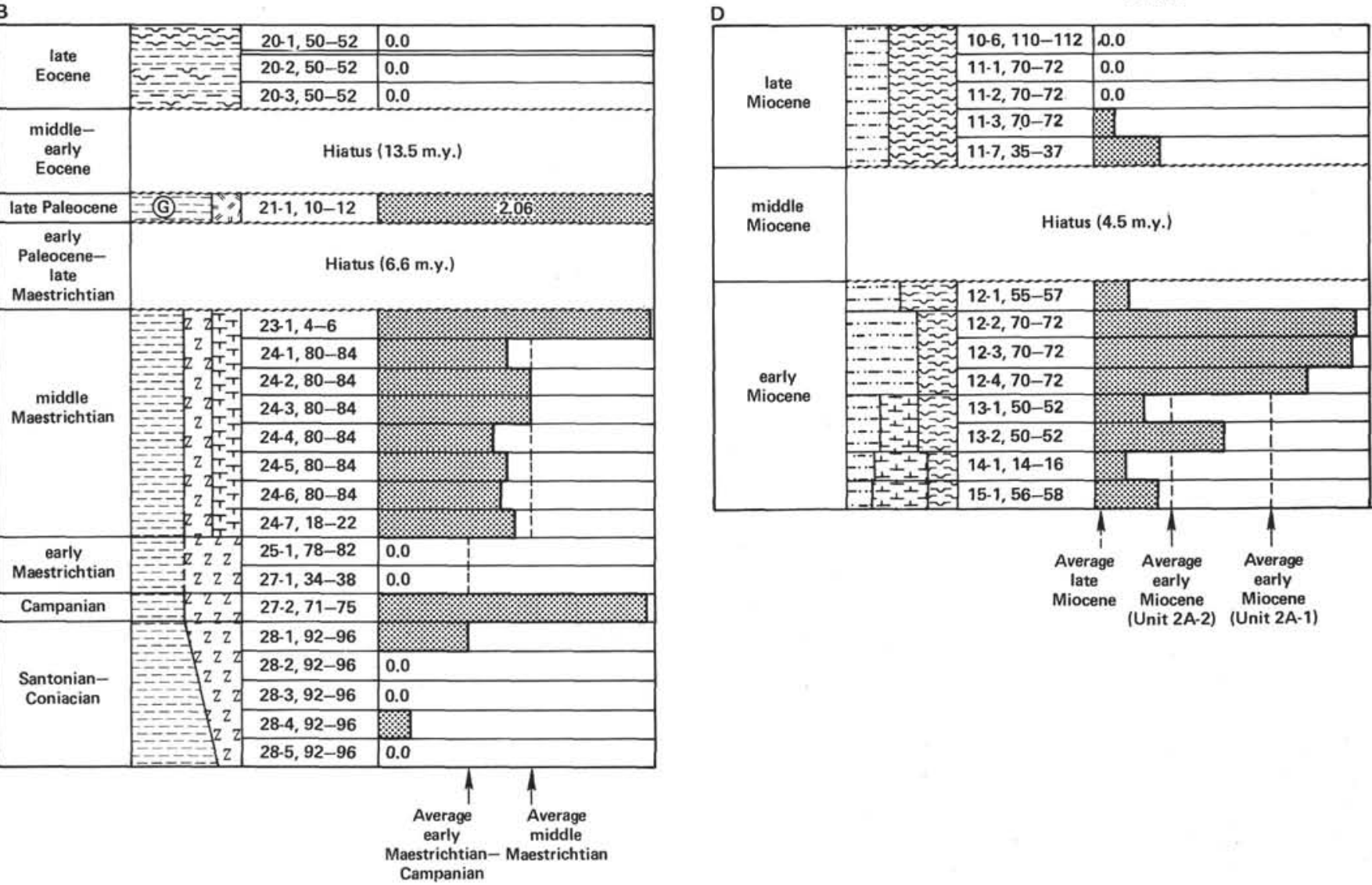

Figure 4. Factor scores distribution of the IIB(-) chemical components assemblage close to the contact of erosional hiatus at three sites. A. The early-middle Albian, Unit 5 to late Cenomanian-Turonian, Hole 511. B. The Mesozoic-Cenozoic and late Paleocene to late Eocene, Hole 511. C. The middle Eocene to middle Miocene, Hole 512. D. The middle Miocene to late Miocene, Hole 513A. 
Table 4. Factor assemblage IIIA(+): Average factor scores.

\begin{tabular}{|c|c|c|c|c|}
\hline Age & Site 511 & Site 512 & Site 514 & Site 513 \\
\hline $\left.\begin{array}{l}\text { Holocene } \\
\text { Pleistocene }\end{array}\right\}$ & $?$ & 1.36 & 0.003 & 0.21 \\
\hline $\begin{array}{l}\text { Pliocene } \\
\text { late } \\
\text { early }\end{array}$ & $\begin{array}{c}\text { Hiatus } \\
?\end{array}$ & Hiatus $\}$ & 0.002 & 0.03 \\
\hline $\begin{array}{l}\text { Miocene } \\
\text { late }\end{array}$ & & 0.04 & & 0.11 \\
\hline $\begin{array}{l}\text { middle } \\
\text { early }\end{array}$ & Hiatus & 0.60 & & $\begin{array}{c}\text { Hiatus } \\
0.07\end{array}$ \\
\hline $\begin{array}{l}\text { Oligocene } \\
\text { late } \\
\text { early }\end{array}$ & $0.04\}$ & Hiatus & & $\begin{array}{l}1.15 \\
0.65\end{array}$ \\
\hline $\begin{array}{l}\text { Eocene } \\
\text { late }\end{array}$ & 0.44 & & & Basalt \\
\hline $\begin{array}{l}\text { middle } \\
\text { early }\end{array}$ & Hiatus & - & & Dasalt \\
\hline $\begin{array}{l}\text { Paleocene } \\
\text { late } \\
\text { early }\end{array}$ & - & & & \\
\hline $\begin{array}{l}\text { Maestrichtian } \\
\text { late } \\
\text { middle } \\
\text { early }\end{array}$ & $\begin{array}{l}\text { Hiatus } \\
0.63\end{array}$ & & & \\
\hline Campanian $\}$ & - & & & \\
\hline $\left.\begin{array}{l}\text { Santonian } \\
\text { Coniacian }\end{array}\right\}$ & 0.10 & & & \\
\hline $\begin{array}{l}\text { Turonian } \\
\text { Cenomanian }\end{array}$ & 2.02 & & & \\
\hline $\begin{array}{l}\text { Albian } \\
\text { late }\end{array}$ & Hiatus & & & \\
\hline $\begin{array}{l}\text { middle } \\
\text { early }\end{array}$ & $\begin{array}{l}1.24 \\
2.09\end{array}$ & & & \\
\hline $\left.\begin{array}{l}\text { Aptian } \\
\text { Barremian } \\
\text { Hauterivian }\end{array}\right\}$ & 1.51 & & & \\
\hline $\begin{array}{l}\text { Valanginian } \\
\text { Berriasian } \\
\text { Portlandian }\end{array}$ & Hiatus & & & \\
\hline $\begin{array}{l}\text { Kimmeridgian } \\
\text { Oxfordian }\end{array}$ & 1.07 & & & \\
\hline
\end{tabular}

Mid-Atlantic Ridge (Holes 514, 513; see Table 5), where the products of basaltoid volcanism play a rather strong role. Thus, the general development of the southwestern Atlantic from a relatively shallow water, closed basin in the Late Jurassic and Early Cretaceous to the Recent ocean was accompanied by an increased accumulation of products of basaltoid volcanism in the sediments.

The rates of $\mathrm{Al}$ accumulation $\left(\mathrm{mg} / \mathrm{cm}^{2} \cdot 10^{3} \mathrm{y}\right.$.) can be regarded as a quantitative criterion for clastic accumulation (Table 6). During most of the Mesozoic (Late Jurassic to Santonian-Coniacian) the basin province of the Falkland Plateau (Hole 511) had rather high $(>20.0 \mathrm{mg}$ / $\mathrm{cm}^{2} \cdot 10^{3} \mathrm{y}$.) rates of $\mathrm{Al}$ accumulation (clastic components). It is interesting that the abnormally high rates ( $>100.0 \mathrm{mg} / \mathrm{cm}^{2} \cdot 10^{3} \mathrm{y}$.) are typical of the intervals of tectonic activity, with increased contributions of clastic material from the nearly continent and, during the Santonian-Coniacian, a larger supply of finely dispersed volcaniclastics.

Compared to the basin province of the Falkland Plateau (Hole 511), the depositional environments in which clastic components accumulated in the northeastern part of the Maurice Ewing Bank (Hole 512) were quite different. In this region the rates of $\mathrm{Al}$ accumulation did not exceed $20.0 \mathrm{mg} / \mathrm{cm}^{2} \cdot 10^{3} \mathrm{y}$. during the middle Eocene to Holocene because of the paleoceanographic distribution of the currents (see Table 6).

For comparison, the maximum rates of $\mathrm{Al}$ accumulation during Cenozoic sedimentation in the eastern and northern regions of the Central Pacific are $15-20 \mathrm{mg} /$ $\mathrm{cm}^{2} \cdot 10^{3} \mathrm{y}$; they reflect intervals with strong contributions of terrigenous material (during the Quaternary). In other equatorial areas of the Pacific Ocean the average rates of $\mathrm{Al}$ accumulation varied during the Tertiary (Pliocene-middle Eocene) from 1.0 to $3.0 \mathrm{mg} / \mathrm{cm}^{2}$. $10^{3} \mathrm{y}$. (Leinen and Stakes, 1979).

High rates of $\mathrm{Al}$ accumulation in the eastern Argentine Basin along the lower western flank of the Mid-Atlantic Ridge can be of a dual nature. During the early Oligocene to late Miocene (see Table 6) fluctuations in the average rates of $\mathrm{Al}$ accumulation can be attributed to both clastic sedimentation and to the biological incorporation of finely dispersed particles by planktonic organisms (von Bennekom and van der Gaast, 1976).

Rather high rates of $\mathrm{Al}$ accumulation $\left(>50 \mathrm{mg} / \mathrm{cm}^{2}\right.$. $10^{3} \mathrm{y}$.) occurred during the Pliocene-Holocene, and abnormally high values $\left(>100 \mathrm{mg} / \mathrm{cm}^{2} \cdot 10^{6} \mathrm{y}\right.$.) were registered in the early Pliocene (see Table 6). Such a rapid accumulation of clastic components can be attributed to increases in the rates of glacial marine sedimentation, basaltoid volcaniclastic accumulation (see Table 5), biogenic incorporation of clastics because of increased biological productivity within the zone of the Antarctic convergence (von Bennekom and van der Gaast, 1976) and possibly to a screening (shielding) effect of the MidAtlantic Ridge, which would favor discharge from a nepheloid layer in the bottom currents.

\section{Manganese and Iron (accumulation of hydrothermal and authigenic components, Tables 7-9)}

An attempt to estimate the role played by hydrothermal and, to some extent, authigenic constituents of sedimentation was made for $\mathrm{Mn}$ and Fe. Relatively reliable assessments of these constituents can be made on the basis of available data on lithology, mineral composition, mode of occurrence (geochemical assemblages) and the rates of $\mathrm{Mn}$ and $\mathrm{Fe}$ accumulation (Bender et al., 1970, 1971; Boström et al., 1973; Leinen and Stakes, 1979; Lyle, 1976; McArthur and Elderfield, 1977). Information on modes of $\mathrm{Mn}$ and $\mathrm{Fe}$ occurrence has already been given (see Tables 1-4 and Appendices A and B; Fig. 4). Distribution of the average $\mathrm{Mn} / \mathrm{Fe}$ values over the main geochronological subdivisions of the deposits (Table 7) can be considered in the context of these data. It should be emphasized that for the post-Middle Jurassic deposits of the southwestern Atlantic the $\mathrm{Mn} / \mathrm{Fe}$ value rarely exceeds 0.070 . (In comparison, Turekian and Wedepohl [1961] give values of 0.131 for deep sea clays and of 0.111 for deep sea carbonates.) The only exception to this rather distinct regional tendency is in the lower-middle Albian sediments $(\mathrm{Mn} / \mathrm{Fe}>0.120)$ from the basin province of the Falkland Plateau, Hole 511. 


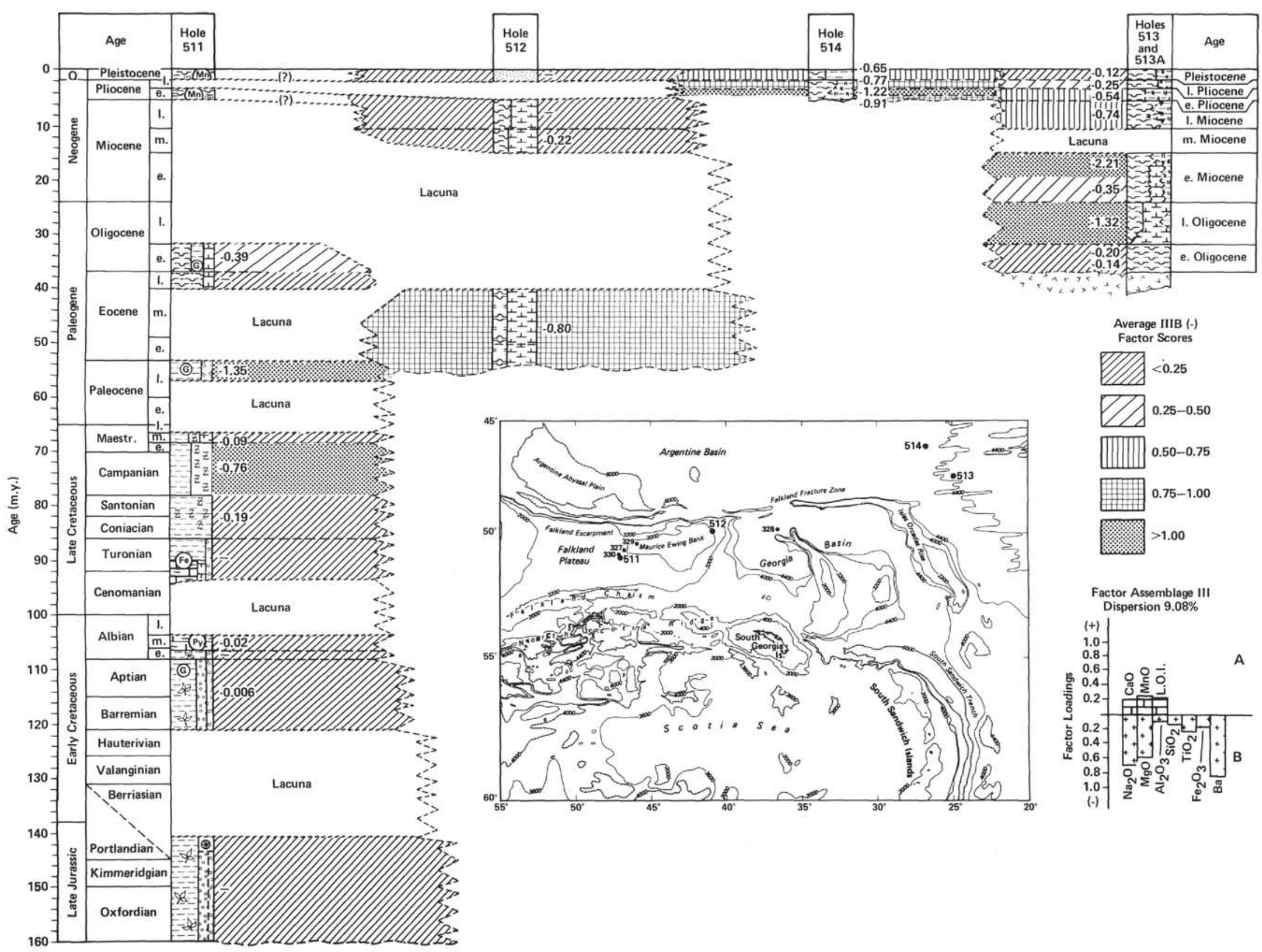

Figure 5. Average factor scores distribution of the IIIB $(-)$ chemical components assemblage in post-Middle Jurassic sediments of the southwestern Atlantic, Leg 71 . The assemblage is represented mainly by barite and associated compounds of $\mathrm{Na}$ and $\mathrm{Mg}$, less by $\mathrm{Ti}$ and $\mathrm{Fe}$. 
Table 5. Ti/Al mean values (wt. ratio).

\begin{tabular}{|c|c|c|c|c|}
\hline Age & Site 511 & Site 512 & Site 514 & Site 513 \\
\hline $\begin{array}{l}\text { Holocene } \\
\text { Pleistocene }\end{array}$ & $?$ & 0.060 & 0.056 & 0.054 \\
\hline $\begin{array}{l}\text { Pliocene } \\
\text { late } \\
\text { early }\end{array}$ & $\begin{array}{c}\text { Hiatus } \\
\quad ?\end{array}$ & Hiatus & $\begin{array}{l}0.056 \\
0.055\end{array}$ & $\begin{array}{l}0.056 \\
0.054\end{array}$ \\
\hline Miocene & & & & \\
\hline $\begin{array}{l}\text { late } \\
\text { middle } \\
\text { early }\end{array}$ & Hiatus & $\begin{array}{l}0.055 \\
0.057\end{array}$ & 0.058 & $\begin{array}{c}0.056 \\
\text { Hiatus } \\
0.055\end{array}$ \\
\hline Oligocene & & & & \\
\hline $\begin{array}{l}\text { late } \\
\text { early }\end{array}$ & $0.051\}$ & Hiatus & & 0.055 \\
\hline Eocene & & & & 0.058 \\
\hline $\begin{array}{l}\text { late } \\
\text { middle } \\
\text { early }\end{array}$ & $\begin{array}{l}0.051 \\
\text { Hiatus }\end{array}$ & 0.052 & & Basalt \\
\hline $\begin{array}{l}\text { Paleocene } \\
\text { late } \\
\text { early }\end{array}$ & 0.055 & & & \\
\hline $\begin{array}{l}\text { Maestrichtian } \\
\text { late } \\
\text { middle }\end{array}$ & Hiatus & & & \\
\hline $\begin{array}{l}\text { middle } \\
\text { early }\end{array}$ & 0.049 & & & \\
\hline Campanian & 0.046 & & & \\
\hline $\left.\begin{array}{l}\text { Santonian } \\
\text { Coniacian }\end{array}\right\}$ & 0.045 & & & \\
\hline $\begin{array}{l}\text { Turonian } \\
\text { Cenomanian }\end{array}$ & 1.045 & & & \\
\hline $\begin{array}{l}\text { Albian } \\
\text { late }\end{array}$ & Hiatus & & & \\
\hline $\begin{array}{l}\text { middle } \\
\text { early }\end{array}$ & $\begin{array}{l}0.042 \\
0.042\end{array}$ & & & \\
\hline $\left.\begin{array}{l}\text { Aptian } \\
\text { Barremian } \\
\text { Hauterivian }\end{array}\right\}$ & 0.044 & & & \\
\hline $\begin{array}{l}\text { Valanginian } \\
\text { Berriasian } \\
\text { Portlandian }\end{array}$ & Hiatus & & & \\
\hline $\left.\begin{array}{l}\text { Kimmeridgian } \\
\text { Oxfordian }\end{array}\right\}$ & 0.046 & & & \\
\hline
\end{tabular}

\begin{tabular}{|c|c|c|c|}
\hline \multicolumn{4}{|c|}{$\begin{array}{l}\text { Standard values after Turekian and Wedepohl, } \\
1961\end{array}$} \\
\hline & $\operatorname{Ti}(\%)$ & $\mathrm{Al}(\%)$ & $\mathrm{Ti} / \mathrm{Al}$ \\
\hline Basalts & 1.38 & 7.8 & 0.177 \\
\hline Ca-granites & 0.34 & 8.2 & 0.041 \\
\hline Clays & 0.46 & 8.0 & 0.0575 \\
\hline Sands & 0.15 & 2.5 & 0.06 \\
\hline $\begin{array}{l}\text { Deep sea } \\
\quad \text { clay sediments }\end{array}$ & 0.46 & 8.4 & 0.0547 \\
\hline $\begin{array}{l}\text { Deep sea } \\
\text { calcareous } \\
\text { sediments }\end{array}$ & 0.077 & 2.0 & 0.0385 \\
\hline
\end{tabular}

This fact can be unambiguously interpreted from the distribution of the average $\mathrm{Mn}$ accumulation rates $(\mathrm{mg} /$ $\mathrm{cm}^{2} \cdot 10^{3} \mathrm{y}$.) for the southwestern Atlantic during postMiddle Jurassic time (Table 8). It is of interest that during the middle to late Albian, in the area of Hole 511, sediments are characterized by maximum rates $(12.20-$ $19.82 \mathrm{mg} / \mathrm{cm}^{2} \cdot 10^{3} \mathrm{y}$.) of $\mathrm{Mn}$ accumulation. For comparison, in the recent pelagic sediments of the World Ocean, the rate of $\mathrm{Mn}$ accumulation varies from 0.2-4.0
Table 6. Average rates of $\mathrm{Al}$ accumulation (in $\mathrm{mg} / \mathrm{cm}^{2} \cdot 10^{3} \mathrm{y}$.).

\begin{tabular}{|c|c|c|c|c|}
\hline Age & Site 511 & Site 512 & Site 514 & Site 513 \\
\hline $\left.\begin{array}{l}\text { Holocene } \\
\text { Pleistocene }\end{array}\right\}$ & ? & 2.89 & 52.71 & 52.89 \\
\hline \multicolumn{5}{|l|}{$\begin{array}{l}\text { Pliocene } \\
\text { Ploce }\end{array}$} \\
\hline late & Hiatus & Hiatus & 122.25 & 84.02 \\
\hline early & $?$ & Hatus & $267.05,318.23$, & 173.78 \\
\hline Miocene & & & 262.37 & \\
\hline late & & 0.29 & & 45.51 \\
\hline middle & & 6.83 & & Hiatus \\
\hline early & Hiatus & & & $21.18,11.70$ \\
\hline \multicolumn{5}{|l|}{ Oligocene } \\
\hline $\begin{array}{l}\text { late } \\
\text { early }\end{array}$ & $130.10\}$ & Hiatus & & $\begin{array}{l}5.09 \\
35.62,27.22\end{array}$ \\
\hline \multicolumn{5}{|l|}{ Eocene } \\
\hline late & 22.34 & & & Basalt \\
\hline $\begin{array}{l}\text { middle } \\
\text { early }\end{array}$ & Hiatus & 19.59 & & \\
\hline \multicolumn{5}{|l|}{ Paleocene } \\
\hline $\begin{array}{l}\text { late } \\
\text { early }\end{array}$ & 10.15 & & & \\
\hline $\begin{array}{l}\text { Maestrichtian } \\
\text { late }\end{array}$ & Hiatus & & & \\
\hline middle & 33.49 & & & \\
\hline $\begin{array}{c}\text { early } \\
\text { Campanian }\end{array}$ & 15.19 & & & \\
\hline $\begin{array}{l}\text { Campanian } \\
\text { Santonian }\end{array}$ & & & & \\
\hline & 264.37 & & & \\
\hline Turonian & 29.94 & & & \\
\hline \multicolumn{5}{|l|}{ Cenomanian } \\
\hline Albian & Hiatus & & & \\
\hline $\begin{array}{l}\text { late } \\
\text { middle }\end{array}$ & 185.27 & & & \\
\hline $\begin{array}{l}\text { middle } \\
\text { early }\end{array}$ & 167.86 & & & \\
\hline Aptian & 38.70 & & & \\
\hline Barremian & 30.10 & & & \\
\hline \multicolumn{5}{|l|}{ Hauterivian } \\
\hline $\begin{array}{l}\text { Valanginian } \\
\text { Berriasian }\end{array}$ & Hiatus & & & \\
\hline $\begin{array}{l}\text { Berriasian } \\
\text { Portlandian }\end{array}$ & & & & \\
\hline Kimmeridgian & 67.88 & & & \\
\hline Oxfordian & & & & \\
\hline
\end{tabular}

$\mathrm{mg} / \mathrm{cm}^{2} \cdot 10^{3} \mathrm{y}$. (Bender et al., 1970. For Pacific Quaternary sediments this parameter is equal to 0.6 , and in the area adjacent to the East Pacific Rise the rate of Mn accumulation varies from 3.0 up to 8.0 (average 5.40) $\mathrm{g} / \mathrm{cm}^{2} \cdot 10^{3} \mathrm{y}$. (Leinen and Stakes, 1979). For sediments of the axial part of the East Pacific Rise the rate of Mn accumulation increases to $24.0-35.0 \mathrm{mg} / \mathrm{cm}^{2} \cdot 10^{3} \mathrm{y}$. (Boström et al., 1973; Bender et al., 1971; Lyle, 1976). Comparison of these data permits one to conclude that clastic and biogenic-clastic sedimentation in the basin province of the Falkland Plateau (Hole 511) during the middle to early Albian was accompanied to a considerable extent by the intense accumulation of hydrothermal $\mathrm{Mn}$, and that the hydrothermal activity in this region was associated with tectonic activity that is related to the rather pronounced erosional hiatus comprising the middle Cenomanian to late Albian (10 m.y.)

Postsedimentary alteration has greatly transformed the products of Mn hydrothermal accumulation. As already mentioned, upper to middle Albian deposits contain distinct manganocalcite molecules (Table 4) which occur either as microspherolitic aggregate patches or as an isomorphic admixture to an altered carbonate constituent of the groundmass. The hydrothermal activity affected the Mn accumulation less distinctly during the 
Table 7. Mn/Fe mean values (wt. ratio).

\begin{tabular}{|c|c|c|c|c|}
\hline Age & Site 511 & Site 512 & Site 514 & Site 513 \\
\hline $\left.\begin{array}{l}\text { Holocene } \\
\text { Pleistocene }\end{array}\right\}$ & $?$ & 0.007 & 0.017 & 0.012 \\
\hline $\begin{array}{l}\text { Pliocene } \\
\text { late } \\
\text { early }\end{array}$ & $\begin{array}{c}\text { Hiatus } \\
?\end{array}$ & Hiatus & $\begin{array}{l}0.016,0.015 \\
0.031\end{array}$ & $\begin{array}{l}0.013 \\
0.014\end{array}$ \\
\hline Miocene & & & & \\
\hline $\begin{array}{l}\text { late } \\
\text { middle } \\
\text { early }\end{array}$ & Hiatus & $\begin{array}{l}0.025 \\
0.016\end{array}$ & & $\begin{array}{l}0.012 \\
\quad \text { Hiatus } \\
0.018,0.054\end{array}$ \\
\hline Oligocene & Hiatus & & & \\
\hline $\begin{array}{l}\text { late } \\
\text { early }\end{array}$ & $0.014\}$ & Hiatus & & $\begin{array}{l}0.021 \\
0.062,0.049\end{array}$ \\
\hline $\begin{array}{c}\text { Eocene } \\
\text { late }\end{array}$ & & & & \\
\hline $\begin{array}{l}\text { late } \\
\text { middle } \\
\text { early }\end{array}$ & $\begin{array}{l}0.022 \\
\text { Hiatus }\end{array}$ & $0.028,0.032$ & & Basalt \\
\hline $\begin{array}{l}\text { Paleocene } \\
\text { late } \\
\text { early }\end{array}$ & 0.007 & & & \\
\hline $\begin{array}{l}\text { Maestrichtian } \\
\text { late }\end{array}$ & Hiatus & & & \\
\hline middle & 0.077 & & & \\
\hline $\begin{array}{c}\text { early } \\
\text { Campanian }\end{array}$ & 0.083 & & & \\
\hline $\begin{array}{l}\text { Santonian } \\
\text { Coniacian }\end{array}$ & 0.034 & & & \\
\hline $\begin{array}{l}\text { Turonian } \\
\text { Cenomanian }\end{array}$ & 0.034 & & & \\
\hline $\begin{array}{l}\text { Albian } \\
\text { late }\end{array}$ & Hiatus & & & \\
\hline $\begin{array}{l}\text { middle } \\
\text { early }\end{array}$ & $\begin{array}{l}0.134 \\
1.251\end{array}$ & & & \\
\hline $\left.\begin{array}{l}\text { Aptian } \\
\text { Barremian } \\
\text { Hauterivian }\end{array}\right\}$ & 0.024 & & & \\
\hline $\begin{array}{l}\text { Valanginian } \\
\text { Berriasian } \\
\text { Portlandian }\end{array}$ & Hiatus & & & \\
\hline $\begin{array}{l}\text { Kimmeridgian } \\
\text { Oxfordian }\end{array}$ & 0.008 & & & \\
\hline
\end{tabular}

\begin{tabular}{|lccc|}
\hline \multicolumn{4}{|c|}{ Average Mn, Fe values } \\
& $\mathrm{Mn}(\%)$ & $\mathrm{Fe}(\%)$ & $\mathrm{Mn} / \mathrm{Fe}$ \\
& & & \\
Basalts & 0.15 & 8.65 & 0.0173 \\
Ca-granites & 0.054 & 2.96 & 0.0182 \\
Clays & 0.085 & 4.72 & 0.0180 \\
Sands & $\times 10^{-4} \%$ & 0.98 & $-\overline{-}$ \\
$\begin{array}{l}\text { Deep sea } \\
\text { clay sediments }\end{array}$ & 0.67 & 6.5 & 0.131 \\
$\begin{array}{l}\text { Deep sea } \\
\quad \text { calcareous }\end{array}$ & 0.10 & 0.90 & 0.111 \\
$\quad$ sediments & & & \\
\hline
\end{tabular}

Santonian-Coniacian at Hole 511 (Table 8). Within this geochronological interval the average rate of $\mathrm{Mn}$ accumulation $\left(5.13 \mathrm{mg} / \mathrm{cm}^{2} \bullet 10^{3} \mathrm{y}\right.$. $)$ is close to that for the areas adjacent to the East Pacific Rise (Leinen and Stakes, 1979), where the hydrothermal contribution of heavy metals was rather evident.

The distribution of average rates of $\mathrm{Fe}$ accumulation (Table 9) during the post-Middle Jurassic sedimentation is similar, as a whole, to that for Mn (Table 8). However, together with hydrothermal products, essential amounts of $\mathrm{Fe}$ in various forms can be also accumulated with basaltoid volcaniclastics, with residual products at the boundaries of erosional hiatuses (metal-rich lag deposits), with clay components, and as an essentially biogen-
Table 8. Average Mn accumulation rates $\left(\mathrm{mg} / \mathrm{cm}^{2} \cdot 10^{3}\right.$ y.).

\begin{tabular}{|c|c|c|c|c|}
\hline Age & Site 511 & Site 512 & Site 514 & Site 513 \\
\hline $\begin{array}{l}\text { Holocene } \\
\text { Pleistocene }\end{array}$ & \} & 0.021 & 0.49 & 0.36 \\
\hline \multicolumn{5}{|l|}{ Pliocene } \\
\hline $\begin{array}{l}\text { late } \\
\text { early }\end{array}$ & $\begin{array}{c}\text { Hiatus } \\
? ?\end{array}$ & Hiatus $\}$ & $\begin{array}{l}1.17 \\
2.55,2.70,\end{array}$ & $\begin{array}{l}0.65 \\
1.38\end{array}$ \\
\hline Miocene & & & 4.68 & \\
\hline late & & 0.005 & & 0.08 \\
\hline middle & & 0.070 & & Hiatus \\
\hline early & Hiatus & & & $0.24,0.38$ \\
\hline \multicolumn{5}{|l|}{ Oligocene } \\
\hline $\begin{array}{l}\text { late } \\
\text { early }\end{array}$ & $0.99\}$ & Hiatus & & $\begin{array}{l}0.59,1.30 \\
1.06\end{array}$ \\
\hline \multicolumn{5}{|l|}{ Eocene } \\
\hline late & 0.27 & & & Basalt \\
\hline $\begin{array}{l}\text { middle } \\
\text { early }\end{array}$ & Hiatus & 0.32 & & \\
\hline \multicolumn{5}{|l|}{ Paleocene } \\
\hline $\begin{array}{l}\text { late } \\
\text { early }\end{array}$ & 0.08 & & & \\
\hline $\begin{array}{l}\text { Maestrichtian } \\
\text { late }\end{array}$ & Hiatus & & & \\
\hline middle & 1.74 & & & \\
\hline $\begin{array}{c}\text { early } \\
\text { Campanian }\end{array}$ & 0.84 & & & \\
\hline Santonian & 5.13 & & & \\
\hline Coniacian & 3.10 & & & \\
\hline $\begin{array}{l}\text { Turonian } \\
\text { Cenomanian }\end{array}$ & 0.56 & & & \\
\hline $\begin{array}{l}\text { Albian } \\
\text { late }\end{array}$ & Hiatus & & & \\
\hline $\begin{array}{l}\text { late } \\
\text { middle }\end{array}$ & 12.20 & & & \\
\hline early & 19.82 & & & \\
\hline Aptian & 0.47 & & & \\
\hline $\begin{array}{l}\text { Barremian } \\
\text { Hauterivian }\end{array}$ & & & & \\
\hline Valanginian & Hiatus & & & \\
\hline $\begin{array}{l}\text { Berriasian } \\
\text { Portlandian }\end{array}$ & Hiatus & & & \\
\hline $\begin{array}{l}\text { Kimmeridgian } \\
\text { Oxfordian }\end{array}$ & 0.26 & & & \\
\hline
\end{tabular}

ic admixture (Martin and Knauer, 1973). Such peculiarities of $\mathrm{Fe}$ geochemistry complicate interpretation of the behavior of this element in processes of sedimentation. The rate of $\mathrm{Fe}$ accumulation (in $\mathrm{mg} / \mathrm{cm}^{2} \cdot 10^{3} \mathrm{y}$.) during the Quaternary for the central part of the Pacific Ocean, except at the East Pacific Rise, is 2.5, whereas in the regions adjacent to the East Pacific Rise this parameter increases up to 15.5-70.0 (average 29.0) (Leinen and Stakes, 1979) and for the East Pacific Rise itself, it is 63.0-110.0 (Boström et al., 1973; Bender et al., 1971). The comparison between the data in Tables 8 and 9 provides additional confirmation of a hydrothermal influx of heavy metals during the middle and early Albian and Santonian-Coniacian into the basin province of the Falkland Plateau (Hole 511). The rate of Fe accumulation there is 78.9-149.1 (Table 9). The high rates of Fe accumulation in the eastern part of the Argentine Basin, along the western flank of the Mid-Atlantic Ridge (Sites 513 and 514) are determined, as a whole, by intense biological productivity (average rate of $\mathrm{Fe}$ accumulation up to 50.0) and hydrothermal effects along the axial zone of the Mid-Atlantic Ridge (Varentsov, 1978). However, the abnormally high rates of $\mathrm{Fe}$ accumulation during the 
Table 9. Average $\mathrm{Fe}$ accumulation rates $\left(\mathrm{mg} / \mathrm{cm}^{2} \cdot 10^{3} \mathrm{y}\right.$.).

\begin{tabular}{|c|c|c|c|c|}
\hline Age & Site 511 & Site 512 & Site 514 & Site 513 \\
\hline $\begin{array}{l}\text { Holocene } \\
\text { Pleistocene }\end{array}$ & $?$ & 2.9 & 29.5 & 28.9 \\
\hline \multicolumn{5}{|l|}{ Pliocene } \\
\hline late & Hiatus & Hiatus & 71.4 & 49.5 \\
\hline early & $?$ & Hatus & $155.9,179.2$ & 101.6 \\
\hline Miocene & & & 150.3 & \\
\hline late & & 0.2 & & 27.7 \\
\hline middle & & 4.4 & & Hiatus \\
\hline early & Hiatus & & & $12.8,7.1$ \\
\hline \multicolumn{5}{|l|}{ Oligocene } \\
\hline $\begin{array}{l}\text { late } \\
\text { early }\end{array}$ & $11.5\}$ & Hiatus & & $\begin{array}{l}28.6 \\
20.8,21.4\end{array}$ \\
\hline \multicolumn{5}{|l|}{ Eocene } \\
\hline late & 11.8 & & & Basalt \\
\hline $\begin{array}{l}\text { middle } \\
\text { early }\end{array}$ & Hiatus & 11.4 & & \\
\hline \multicolumn{5}{|l|}{ Paleocene } \\
\hline $\begin{array}{l}\text { late } \\
\text { early }\end{array}$ & 12.3 & & & \\
\hline $\begin{array}{l}\text { Maestrichtian } \\
\text { late }\end{array}$ & Hiatus & & & \\
\hline middle & 22.7 & & & \\
\hline $\begin{array}{c}\text { early } \\
\text { Campanian }\end{array}$ & 10.1 & & & \\
\hline \multicolumn{5}{|l|}{ Santonian } \\
\hline Coniacian & 149.1 & & & \\
\hline Turonian & 16.1 & & & \\
\hline \multicolumn{5}{|l|}{ Cenomanian } \\
\hline $\begin{array}{c}\text { Albian } \\
\text { late }\end{array}$ & Hiatus & & & \\
\hline middle & 91.2 & & & \\
\hline early & 78.9 & & & \\
\hline $\begin{array}{l}\text { Aptian } \\
\text { Barremian }\end{array}$ & 19.7 & & & \\
\hline $\begin{array}{l}\text { Barremian } \\
\text { Hauterivian }\end{array}$ & & & & \\
\hline Valanginian & Hiatus & & & \\
\hline Berriasian & & & & \\
\hline Portlandian & & & & \\
\hline $\begin{array}{l}\text { Kimmeridgian } \\
\text { Oxfordian }\end{array}$ & 31.6 & & & \\
\hline
\end{tabular}

early Pliocene (101.6-179.2) regionally traced in both sequences (see Sites 513 and 514; Table 9) can be interpreted as an intense outburst of hydrothermal activity during this time within the Mid-Atlantic Ridge zone.

\section{Barium (accumulation of biogenic components, Tables 10, 11)}

Barium can serve as a component that shows the peculiarities of the biogenic constituent of sedimentation. However, $\mathrm{Ba}$ is a typical element of metal-bearing hydrothermal sediments. Thus, interpretations of its geochemical behavior can be made in the context of information as broad as for $\mathrm{Mn}$ and $\mathrm{Fe}$ (Chester, 1965; Chester and Aston, 1976; Goldberg and Arrhenius, 1958; Gurvich et al., 1978).

$\mathrm{The} \mathrm{Ba} / \mathrm{Al}$ ratio is a criterion for the intensity of $\mathrm{Ba}$ accumulation with the primary diluting effect being such biogenic components as $\mathrm{CaCO}_{3}$ and $\mathrm{SiO}_{2}$. The distribution of this ratio (Table 10) permits a subdivision of the history of post-Middle Jurassic sedimentation into two intervals: (a) late Mesozoic, with a $\mathrm{Ba} / \mathrm{Al}$ ratio not exceeding 0.020 and (b) Cenozoic with predominantly biogenic sediments for which the $\mathrm{Ba} / \mathrm{Al}$ ratio does not
Table 10. BA/Al mean values (wt, ratio).

\begin{tabular}{|c|c|c|c|c|}
\hline Age & Site 511 & Site 512 & Site 514 & Site 513 \\
\hline $\begin{array}{l}\text { Holocene } \\
\text { Pleistocene }\end{array}$ & $?$ & 0.013 & 0.016 & 0.020 \\
\hline $\begin{array}{l}\text { Pliocene } \\
\text { late }\end{array}$ & Hiatus & Hiatus & $\begin{array}{l}0.019 \\
0.021\end{array}$ & 0.019 \\
\hline early & $?$ & & 0.022 & 0.017 \\
\hline Miocene & & & & \\
\hline late & & 0.039 & & $\begin{array}{l}0.018 \\
\text { Hiatus }\end{array}$ \\
\hline $\begin{array}{l}\text { middle } \\
\text { early }\end{array}$ & Hiatus & 0.037 & & $\begin{array}{l}\text { Hiatus } \\
0.026\end{array}$ \\
\hline Oligocene & & & & \\
\hline $\begin{array}{l}\text { late } \\
\text { early }\end{array}$ & $0.018\}$ & Hiatus & & $\begin{array}{l}0.031,0.040 \\
0.031\end{array}$ \\
\hline Eocene & & & & 0.058 \\
\hline late & 0.024 & & & Basalt \\
\hline $\begin{array}{l}\text { middle } \\
\text { early }\end{array}$ & Hiatus & $0.044,0.056$ & & \\
\hline Paleocene & & & & \\
\hline $\begin{array}{l}\text { late } \\
\text { early }\end{array}$ & $?$ & & & \\
\hline $\begin{array}{l}\text { Maestrichtian } \\
\text { late }\end{array}$ & Hiatus & & & \\
\hline middle & 0.022 & & & \\
\hline $\begin{array}{c}\text { early } \\
\text { Campanian }\end{array}$ & 0.016 & & & \\
\hline $\begin{array}{l}\text { Santonian } \\
\text { Coniacian }\end{array}$ & 0.013 & & & \\
\hline $\begin{array}{l}\text { Turonian } \\
\text { Cenomanian }\end{array}$ & 0.004 & & & \\
\hline $\begin{array}{l}\text { Albian } \\
\text { late }\end{array}$ & Hiatus & & & \\
\hline $\begin{array}{l}\text { middle } \\
\text { early }\end{array}$ & $\begin{array}{l}0.015 \\
1.006\end{array}$ & & & \\
\hline $\begin{array}{l}\text { Aptian } \\
\text { Barremian } \\
\text { Hauterivian }\end{array}$ & 0.009 & & & \\
\hline $\begin{array}{l}\text { Valanginian } \\
\text { Berriasian } \\
\text { Portlandian }\end{array}$ & Hiatus & & & \\
\hline $\left.\begin{array}{l}\text { Kimmeridgian } \\
\text { Oxfordian }\end{array}\right\}$ & 0.009 & & & \\
\hline
\end{tabular}

\begin{tabular}{|lccc|}
\hline \multicolumn{5}{|c|}{ Average $\mathrm{Ba} / \mathrm{Al}$ values } \\
& $\mathrm{Ba}(\%)$ & $\mathrm{Al}(\%)$ & $\mathrm{Ba} / \mathrm{Al}$ \\
Basalts & 0.033 & 7.8 & 0.0042 \\
Ca-granites & 0.042 & 8.2 & 0.0051 \\
Clays & 0.058 & 8.0 & 0.0072 \\
Sands & $\times 10^{-3}$ & 2.5 & - \\
$\begin{array}{l}\text { Deep sea } \\
\text { clay sediments }\end{array}$ & 0.23 & 8.4 & 0.0274 \\
$\begin{array}{l}\text { Deep sea } \\
\text { calcareous }\end{array}$ & 0.019 & 2.0 & 0.0095 \\
$\quad$ & & & \\
\hline sediments & & & \\
\hline
\end{tabular}

exceed, as a rule, 0.015-0.020, except during periods of intense biological productivity accompanied by the accumulation of carbonate and siliceous oozes, for which the $\mathrm{Ba} / \mathrm{Al}$ ratio exceeds 0.030 (see Table 10). However, in cases where clastic components considerably predominate, the $\mathrm{Ba} / \mathrm{Al}$ ratio fails to identify the biogenic constituent. The rates of $\mathrm{Ba}$ accumulation (in $\mathrm{mg} / \mathrm{cm}^{2}$. $10^{3} \mathrm{y}$.) can serve as an indicator of the intensity of the processes concerned (Table 11). Geochronological intervals with abnormally high rates should be emphasized in 
Table 11. Average $\mathrm{Ba}$ accumulation rates $\left(\mathrm{mg} / \mathrm{cm}^{2} \cdot 10^{3} \mathrm{y}.\right)$.

\begin{tabular}{|c|c|c|c|c|}
\hline Age & Site 511 & Site 512 & Site 514 & Site 513 \\
\hline $\begin{array}{l}\text { Holocene } \\
\text { Pleistocene }\end{array}$ & $?$ & 0.036 & 0.835 & 1.07 \\
\hline \multicolumn{5}{|l|}{ Pliocene } \\
\hline late & Hiatus & Hiatus & 2.26 & 1.62 \\
\hline early & $?$ & & $4.94,6.53$ & 3.03 \\
\hline \multicolumn{5}{|l|}{ Miocene } \\
\hline late & & 0.011 & & 0.77 \\
\hline $\begin{array}{l}\text { middle } \\
\text { early }\end{array}$ & Hiatus & 0.250 & & Hiatus \\
\hline \multicolumn{5}{|l|}{ Oligocene } \\
\hline $\begin{array}{l}\text { late } \\
\text { early }\end{array}$ & $2.39\}$ & Hiatus & & $2.02,1.14$ \\
\hline \multicolumn{5}{|l|}{ Eocene } \\
\hline late & 0.53 & & & Basalt \\
\hline $\begin{array}{l}\text { middle } \\
\text { early }\end{array}$ & Hiatus & 0.88 & & \\
\hline \multicolumn{5}{|l|}{ Paleocene } \\
\hline $\begin{array}{l}\text { late } \\
\text { early }\end{array}$ & $?$ & & & \\
\hline \multirow{2}{*}{$\begin{array}{l}\text { Maestrichtian } \\
\quad \text { late } \\
\text { middle } \\
\text { early }\end{array}$} & Hiatus & & & \\
\hline & 0.74 & & & \\
\hline $\begin{array}{c}\text { early } \\
\text { Campanian }\end{array}$ & 0.24 & & & \\
\hline \multirow{2}{*}{\multicolumn{5}{|c|}{$\begin{array}{l}\text { Santonian } \\
\text { Coniacian }\end{array}$}} \\
\hline & & & & \\
\hline \multicolumn{5}{|l|}{ Turonian } \\
\hline \multicolumn{5}{|l|}{$\begin{array}{l}\text { Albian } \\
\text { late }\end{array}$} \\
\hline middle & 2.76 & & & \\
\hline early & 1.05 & & & \\
\hline $\left.\begin{array}{l}\text { Aptian } \\
\text { Barremian }\end{array}\right\}$ & 0.35 & & & \\
\hline Hauterivian & & & & \\
\hline Valanginian & Hiatus & & & \\
\hline $\begin{array}{l}\text { Berriasian } \\
\text { Portlandian }\end{array}$ & Hatus & & & \\
\hline $\begin{array}{l}\text { Kimmeridgian } \\
\text { Oxfordian }\end{array}$ & 0.61 & & & \\
\hline
\end{tabular}

Note: $<0.20$, low rates; $0.20-1.00$, moderate rates; $>1.00$, high rates.

considering the rates of $\mathrm{Ba}$ accumulation in the Late $\mathrm{Ju}$ rassic to Cretaceous sediments (Hole 511), i.e., the middle to lower Albian (Unit 6, 1.05; Unit 5, 2.76) and Santonian-Coniacian (3.32). By comparison, the $\mathrm{Ba}$ accumulation rate in Quaternary deposits of the South $\mathrm{Pa}$ cific zone with high biological productivity is $0.5-5.5$ (average 2.8). In the metal-bearing sediments in the eastern part of this zone and in the areas of the East Pacific Rise such rates are much lower. In Pacific regions with rather limited biological productivity, e.g., South Basin, the rates of $\mathrm{Ba}$ accumulation are lower than 0.1-0.2 (Gurvich et al., 1978). I mentioned earlier that rather high rates of $\mathrm{Mn}$ and $\mathrm{Fe}$ accumulation typical of hydrothermal metal-bearing oceanic sediments were registered in the sediments of the same geochronological intervals (see Tables 8, 9, 11). These, along with relatively high rates of $\mathrm{Ba}$ accumulation in the sediments at erosional hiatuses, can be interpreted as an indication of residual barite accumulation: the early Oligocene, late Eocene and middle Maestrichtian of Hole 511; the middle Eocene at Hole 512; the middle and late Miocene at Hole
513 (see Table 11). However, for Cenozoic sediments of the eastern Argentine Basin (Holes 513 and 514), the accumulation rates are in most cases not lower than 1.0 (see Table 11). Particularly remarkable is the early Pliocene (Hole 513) to Pliocene (Hole 514) interval with rather high rates: Ba more than 2.00 (up to 6.53) (Table 11). The same geochronological intervals also show rather high rates of $\mathrm{Mn}$ and $\mathrm{Fe}$ accumulation (see Table 9), the nature of which was considered earlier.

The interpretation of these data should account for the fact that at the end of the early Oligocene and at the end of the early Miocene (see Figs. 2 and 3 ) the opening of the Drake Passage gave rise to pulsations of the nutrient-rich Antarctic waters to the north (Boltovskoy, 1980; Ciesielski and Wise, 1977; Kennett and Shackleton, 1976). This most significant paleoceanographical event was accompanied by the subsidence of the oceanic floor plus fluctuations and a general decrease in the carbonate compensation depth (CCD). The northern boundary of the Polar Front is manifested in rather high rates of $\mathrm{Ba}$ and $\mathrm{SiO}_{2}$ accumulation as a result of high productivity in Antarctic waters. Rather high rates of Ba accumulation are registered predominantly in Neogene and Quaternary sediments which contain abundant siliceous fossils. We can assume that a considerable increase in the rates of $\mathrm{Ba}$ accumulation during the early Pliocene (Hole 513) and Pliocene (Hole 514, see Table 11) resulted from the fact that this interval was accompanied by fluctuations in movements of Antarctic waters rich in nutrients which followed a drastic change from a warmer climate during the late Miocene. The high rates of $\mathrm{Ba}$ accumulation in Oligocene sediments represented by foraminiferal-siliceous nannofossil oozes testify to the high biological productivity of that time under conditions of relatively shallower ocean floor depths and a relatively lower position of the CCD.

Thus for the study area (Sites 511, 513, and 514) the geochronological intervals which show high rates of $\mathrm{Ba}$ accumulation are, at least, of a dual nature. On the one hand, during the middle-early Albian and SantonianConiacian (Site 511) an intense accumulation of $\mathrm{Ba}$, $\mathrm{Mn}$, and Fe took place with moderate biogenic transformation of these components. This can be evidenced by low amounts of $\mathrm{SiO}_{2}$ and $\mathrm{CaCO}_{3}$ in sediments. On the other hand, during the Pliocene rather appreciable amounts of $\mathrm{Ba}, \mathrm{Mn}$, and $\mathrm{Fe}$ were supplied with hydrothermal emissions from the axial part of the Mid-Atlantic Ridge. Where these were injected into the zone of high biological productivity (Sites 513 and 514), they and hydrogenic components contributed by Antarctic waters in the area of the Polar Front (Ludwig et al., 1980; Martin and Knauer, 1973), were subjected to intense biochemical reworking.

\section{GEOCHEMICAL HISTORY OF POST-MIDDLE JURASSIC SEDIMENTATION}

Brief information on the lithology and geochemistry of post-Middle Jurassic sedimentation is given in Barker, Dalziel, et al. (1977); Ludwig et al. (1980); Tarney and Donnellan (1977); Thompson (1977). In the chapter on the geochemistry of trace elements (Varentsov, this 
volume) the problems of late Mesozoic sedimentation in the basin province of the Falkland Plateau are discussed.

This study of the geochemistry of major components in post-Middle Jurassic deposits of the southwestern Atlantic throws additional light on these problems.

Stage I. Middle to Late Jurassic to Early Cretaceous, 160.0-106.0 Ma (sedimentation in a shallow basin)

\section{Late Jurassic, 160.0-140.0 Ma}

During the Late Jurassic (this may also include the Middle Jurassic; see Barker, Dalziel, et al., 1977, and Thompson, 1977) mostly clay sediments were deposited, along with appreciable amounts of sapropelic and detrital organic matter (up to 7\%). The mineral composition of these sediments is described elsewhere (Varentsov; Varentsov et al.; both this volume). The clastic sediments accumulated in a shallow-water basin where the bottom water layers were characterized by a stagnant oxygenfree regime. The significant amount of granitoid materials in the clastic matter of sediments is indicated by the relatively low $\mathrm{Ti} / \mathrm{Al}$ value $(0.046$; see Table 5$)$, which is close to the ratio for Ca-granites $(0.041$, according to Turekian and Wedepohl, 1961). The rate of clastic sedimentation is indicated by the rate of $\mathrm{Al}$ sedimentation. In this case, the value of $67.88 \mathrm{mg} / \mathrm{cm}^{2} \cdot 10^{3} \mathrm{y}$. considerably exceeds the maximum rates for the Quaternary deposition of $\mathrm{Al}(20.0)$ in coastal parts of the Pacific Ocean (Leinen and Stakes, 1979).

\section{Late Jurassic: Portlandian to Early Cretaceous (Hauterivian), 140.0-121.0 Ma (hiatus in sedimentation)}

The erosional hiatus reflects what is probably the most important event in this paleoceanographical history: the breakup of the Gondwanaland supercontinent and the initial formation of the South Atlantic (Barker, Dalziel, et al., 1977; Ludwig et al., 1980; Thompson, 1977).

\section{Early Cretaceous: Aptian-Barremian to middle-early Albian Accumulation of the Upper Portion of Lithologic Unit 6, 121.0-106.0? Ma}

This period is characterized by the accumulation of sediments similar in composition and facies to those of the Late Jurassic. However, noticeable deepening and extension of the basin resulted in much lower rates of $\mathrm{Al}$ accumulation during the Aptian-Barremian $(38.70 \mathrm{mg}$ / $\mathrm{cm}^{2} \cdot 10^{3} \mathrm{y}$.), as compared to the Late Jurassic (see Table $6)$.

The lower Albian sediments (still during the time of Lithologic Unit 6) are similar in lithology and facies to those of the Aptian-Barremian. However, they are characterized by rather high accumulation rates $\left(\mathrm{mg} / \mathrm{cm}^{2}\right.$. $10^{3} \mathrm{y}$.) of $\mathrm{Al}(167.86), \mathrm{Mn}(19.82), \mathrm{Fe}$ (78.90), Ba (1.05), with the $\mathrm{Mn} / \mathrm{Fe}$ ratio 1.251 and the $\mathrm{Ti} / \mathrm{Al}$ ratio 0.042 (see Tables 5-6, 8-11). These data provide evidence on the initiation of sedimentation of fine-clastic granitoid material accompanied by high input of hydrothermal components: $\mathrm{Mn}, \mathrm{Fe}$, and $\mathrm{Ba}$. The accumulation rates of the latter are comparable with those of metalliferous sediments of axial zones (see details earlier).
Stage 2. Middle-early Albian to middle Maestrichtian, 106.0?-66.6 Ma (sedimentation in an open oceanic basin)

\section{Middle-early Albian (accumulation of Lithologic Unit 5), 106.0?-104.0 Ma}

In the second half of the middle-early Albian a considerable change in conditions of sedimentation took place: multicolored (red in the upper part of the interval) mostly clay nannofossil oozes of the open sea accumulated together with disseminated $\mathrm{Fe}$ - and Mn-hydroxides (an admixture of basic-intermediate volcanogenic material). Judged by data on benthic foraminifers, the basin was from 100-400 meters deep (Barker, Dalziel, et al., 1977). This period was characterized by high sedimentation rates of clastic materials (acid-intermediate in composition; $\mathrm{mg} / \mathrm{cm}^{2} \bullet 10^{3} \mathrm{y}$.): $\mathrm{Al} 185.27, \mathrm{Ti} / \mathrm{Al} \mathrm{0.042}$; rapid supply of mostly hydrothermal components subjected to considerable biogenic and postsedimentary reworking (Mn 12.20, Fe 91.2, Ba 2.76, with $\mathrm{Mn} / \mathrm{Fe} 0.134$; see Tables 5-9, 11). Noteworthy is the fact that in regions near the axial zone of the East Pacific Rise the accumulation rate of $\mathrm{Mn}$ is 3.0-8.0 (average 5.4); of Fe; 15.0-70.0 (average 29.0) (Leinen and Stakes, 1979); of $\mathrm{Mn}$ in metalliferous sediments, 24.0-35.0, and of $\mathrm{Fe}$, 63.0-110.0 (Boström et al., 1973; Bender et al., 1971; Lyle, 1976). Higher hydrothermal activity and outbursts of basaltoid volcanism at the end of this interval (see Varentsov, this volume) can be related both to the expansion and deepening of the sea basin and to tectonic activity before the erosional hiatus.

\section{Late Albian to the End of the late Cenomanian, (104.0-94.0? Ma (hiatus in sedimentation)}

The hiatus is connected with deepening and expansion of the developing South Atlantic basin and with the initiation of currents passing between the eastern and western parts of Antarctica (Barker, Dalziel, et al., 1977).

\section{The End of the late Cenomanian to the Turonian, 94.0?-86.0 Ma}

Mostly clay sediments were deposited, admixed with nannofossils and foraminiferal remains, dispersed $\mathrm{Fe}$ hydroxides, basic volcanoclastic materials, and fragments of pelecypods. Further expansion and deepening of the open oceanic basin took place.

Accumulation rates and ratios recorded for $\mathrm{Al}$ (29.94, with Ti/Al 0.45), Mn (0.56), $\mathrm{Fe}$ (16.10, with $\mathrm{Mn}$ / $\mathrm{Fe} 0.034), \mathrm{Ba}(0.13)$ (Tables $5-9,11)$, can be regarded as indications of a moderate supply of clastic material into the marginal areas of the developing oceanic basin, the endogenic influence being rather insignificant.

\section{Coniacian-Santonian, 86.0-78.0 Ma}

During this time predominantly clay sediments with appreciable amounts of heulandite in the later part developed after fine-dispersed basic volcaniclastics. Sedimentation proceeded in an open oceanic basin (depths over $2000 \mathrm{~m}$ ) below the CCD with an active circulation of meridionally directed currents (Barker, Dalziel, et al., 1977). Noteworthy are abnormally high rates of clas- 
tic sedimentation, chiefly andesitic, at the end of the interval (fine-dispersed basaltoid volcaniclastics with a pronounced hydrothermal influence; accumulation rates and ratios were $\mathrm{Al} 264.37 ; \mathrm{Ti} / \mathrm{Al} 0.045 ; \mathrm{Mn} 5.13 ; \mathrm{Fe}$ 149.10; $\mathrm{Mn} / \mathrm{Fe} 0.034$; and $\mathrm{Ba} 3.32$ (see Tables 5-9, 11). These data convincingly show that the hydrothermal nature of large amounts of $\mathrm{Mn}, \mathrm{Fe}, \mathrm{Ba}$, and other heavy metals is concealed to an appreciable extent by the diluting effect of clastic components. Criteria for evaluating the role of biogenic constituents are uncertain, as there are almost no siliceous fossils in the sediments. This may be a result of dissolution and of postsedimentary transformations.

\section{Campanian-early Maestrichtian, 78.0-68.3 Ma}

This interval is characterized by clay sedimentation with appreciable amounts of fine andesitic and lesser amounts of basaltic volcaniclastics altered into heulandite (up to $70 \%$ ).

The accumulation of these sediments was characterized by rates peculiar to clastic sedimentation in marginal areas of the open ocean, without pronounced endogenic activity and below the critical CCD. Accumulation rates and ratios were $\mathrm{Al} 15.19 ; \mathrm{Ti} / \mathrm{Al} 0.046 ; \mathrm{Mn} \mathrm{0.84} ; \mathrm{Fe}$ 10.10; $\mathrm{Mn} / \mathrm{Fe} 0.083 ; \mathrm{Ba} 0.24$; Tables 5-9, 11.

\section{Middle Maestrichtian, 68.3-66.4 Ma}

Mainly clay sediments admixed with nannofossils and zeolitized basic volcaniclastics accumulated. The core samples contain accumulations of phosphates, authigenic hydromicas, and $\mathrm{Fe}$ - and Mn-hydroxides which are peculiar sediments near the boundary of a large erosional hiatus. These are displayed by the $\operatorname{IIB}(-)$ factor assemblage of the components (Tables 1-2, 4, Appendices A, B; see Varentsov; and Varentsov et al., both this volume). High rates of $\mathrm{Al}$ sedimentation can be explained, first, by residual concentrations of these components from large masses of a sediment. Accumulation rates (in $\mathrm{mg} / \mathrm{cm}^{2} \cdot 10^{3} \mathrm{y}$.) and ratios were, for $\mathrm{Al}, 33.49$; Ti/Al 0.049; Mn 1.47; Fe 22.70; Ba 0.74; see Tables 5-9 and 11.

\section{Stage 3. Late Maestrichtian to late-middle Eocene, 66.4-57.0? Ma (erosional hiatus in sedimentation)}

The hiatus is almost global in character. Significant aspects in the reconstruction of the paleoceanographical system of the currents of this time are considered in Barker, Dalziel, et al., 1977; Ciesielski and Wise, 1977; Ludwig et al., 1980; Loutit and Kennett, 1981; McCoy and Zimmerman, 1977; Thiede, 1981; and Thiede and van Andel, 1977.

\section{Stage 4. Late-middle Eocene to early Miocene, 57.0?-15.0 Ma}

For the southwestern Atlantic this was a time of further expansion and deepening of the ocean, considerable change in the system of paleocurrents, and intense biogenic sedimentation. The combination of these paleoceanographical factors resulted in the development of marked erosional hiatuses divided by intervals of intense carbonate and, to a lesser extent, siliceous sedimentation; for the distribution of carbonate components, see factor assemblage IB $(-)$ and of siliceous components, factor assemblage IIA(+); Figs. 2 and 3. Sediments of the boundary zones of these erosional hiatuses are characterized by pronounced accumulations of residual products; see factor assemblage IIB(-), Table 2, Fig. 4. These are represented by phosphates, authigenic clay minerals, and $\mathrm{Fe}$ - and Mn-hydroxides (see Varentsov et al., this volume). The rates of $\mathrm{CaCO}_{3}$ and $\mathrm{SiO}_{2}$ accumulation (see Appendices A and B) at this time are comparable with these parameters in the recent zones of high biological productivity at the relatively large critical carbonate compensation depth (Bezrukov and Romankevich, 1970; Bogdanov and Chekhovskich, 1979; Lisitzin, 1978). The accumulation rates of clastic components did not exceed, as a rule, those of $\mathrm{Al}\left(50 \mathrm{mg} / \mathrm{cm}^{2} \cdot 10^{3} \mathrm{y}\right.$.) and basaltoid material played a significant role (Tables $5,6)$. Considerable rates of $\mathrm{Fe}$ accumulation and to a lesser extent of $\mathrm{Mn}$ in the eastern part of the Argentine Basin (see Tables 8, 9) are of a dual nature: (a) hydrothermal exhalations of axial zones (Varentsov, 1978); and (b) biogenic incorporation of exhalation and hydrogenic components by planktonic organisms (Martin and Knauer, 1973; von Bennekom and van der Gaast, 1976). The rates of $\mathrm{Ba}$ accumulation (see Table 11) reflect the intensity of biogenic sedimentation: during the middle Eocene (Site 512) to late Oligocene this parameter exceeded $0.50 \mathrm{mg} / \mathrm{cm}^{2} \cdot 10^{3} \mathrm{y}$, and in the regions of the western slope of the Mid-Atlantic Ridge (Site 513) it increased, in the second half of the late Oligocene, to 2.02. These values are close to rates recorded in Recent sediments of the southern Pacific Ocean, which are characterized by high biological productivity: $0.5-5.5$, average 2.8 (Gurvich et al., 1978).

\section{Stage 5. Neogene-Quaternary, $15 \mathrm{Ma}$ to the present day)}

The main Cenozoic paleoceanographical event of the southwestern Atlantic, one which affected the character of sedimentation over the greater part of the World Ocean, was the opening of the Drake Passage during the late Oligocene to early Miocene, an event related to the appreciable reconstruction of the major current systems (Barker, Dalziel, et al., 1977; Boltovskoy, 1980; Ciesielski and Wise, 1977; Kennett and Shackleton, 1976; Loutit and Kennett, 1981; Ludwig et al., 1980; McCoy and Zimmerman, 1977). Northward fluctuations of the Polar Front Zone and the incursion into the Atlantic of Antarctic waters rich in nutrients resulted in a sharp decrease in the CCD and a massive accumulation of siliceous biogenic sediments. Some time after the initiation of new current systems in the study area, glacial marine sedimentation began, thus accounting for the high rates of clastic accumulation in the uppermost Miocene-Holocene sediments.

As a result of widespread erosion over the Falkland Plateau, the middle-upper Miocene sediments were preserved only at the Leg 71 drill site on the northeastern Maurice Ewing Bank (Hole 512, Figs. 2 and 3). These sediments are biogenic carbonate-siliceous oozes. Noteworthy is the fact that from the middle Eocene through 
the Miocene this area was located above the CCD. Clastic sedimentation was characterized by a restricted supply of material composed mostly of decomposition products of median-basic rocks; the rate of $\mathrm{Al}$ accumulation is less than $20.0 \mathrm{mg} / \mathrm{cm}^{2} \cdot 10^{3} \mathrm{y}$. with $\mathrm{Ti} / \mathrm{Al}$ over 0.050 (see Tables 5 and 6). Accumulation of $\mathrm{Mn}, \mathrm{Fe}$, and $\mathrm{Ba}$ was not above the rates representative of pelagic areas of the open ocean (see Tables 8, 9, and 11). These data show that within the Falkland Plateau the invasion of cold Antarctic waters into the South Atlantic had little effect through the early-late Miocene.

A quite different picture is observed in the younger sediments to the north, in the eastern Argentine Basin (Sites 513 and 514; see Figs. 2 and 3). During the late Miocene clay diatomaceous oozes marked the beginning of sedimentation under conditions of the advancing Polar Front. It was the Pliocene, however, that saw a considerable northward advance of the Polar Front Zone in this region. This geochronological interval was characterized by quite high rates of clastic, biogenic, and (a result of influence from the axial part of the Ridge) hydrothermal constituents of sedimentation. Accumulation rates and ratios (in $\mathrm{mg} / \mathrm{cm}^{2} \cdot 10^{3} \mathrm{y}$.) were $\mathrm{Al}$ up to 318.23 , with $\mathrm{Ti} / \mathrm{Al}$ up to $0.058 ; \mathrm{Mn}$ up to $4.68 ; \mathrm{Fe} 179.20 ; \mathrm{Ba}$ up to 6.53. During the Quaternary the geochemical characteristics of sedimentation in the open part of the southwestern Atlantic (Sites 513 and 514) changed only slightly compared to the Pliocene: some southward migration of the Polar Front Zone took place, accompanied by a weakening of biological productivity and an increase in the accumulation of glacial marine sediments. The southwestern Atlantic was characterized by present-day parameters of sedimentation.

\section{CONCLUSION}

Study of the geochemistry of major components and of $\mathrm{Ba}$ and $\mathrm{Sr}$ in the context of the available data on lithology, mineralogy, and other geological information enabled me to evaluate quantitatively the biogenic, clastic, authigenic, and hydrothermal constituents of postMiddle Jurassic sedimentation in the southwestern Atlantic. Special attention was paid to the average rates of component accumulation. Factor analysis (R-mode) of the analytical data allowed us to follow the development in time and space of paragenetic assemblages of the components. Six main assemblages were identified (Table 1). Using the data from study of these assemblages, five main stages in the geochemical history of post-Middle-Jurassic sedimentation were identified and analyzed in detail.

\section{ACKNOWLEDGMENTS}

The author is obliged to his colleagues at the Geological Institute of the U.S.S.R. Academy of Sciences: D. A. Kazimirov (Laboratory of Mathematical Research Methods), N. I. Kartoshkina, and N. Y. Vlasova for their help in mathematical processing the data and preparing the materials for publication; N. K. Mirskaya, E. I. Pyatigorskaya for assistance in graphic presentation of the materials; and G. N. Surovtseva for translation of the paper into English.

Appreciable help in implementation and control of X-ray fluorescent and chemical analyses was rendered by L. V. Tauson, V. P. Afo- nin, L. V. Chernyshov, and V. F. Geletiy (Institute of Geochemistry at the Siberian Branch of the U.S.S.R. Academy of Sciences, Irkutsk).

Critical review of the paper and comments by A. G. Kossovskaya and V. I. Muraviev improved the work.

\section{REFERENCES}

Bender, M. L. Broecker, W., Gornitz, V., et al., 1971. Geochemistry of three cores from the East Pacific Rise. Earth Planet. Sci. Lett., $12: 425-433$.

Bender, M. L., Ku, T.-L., and Broecker, W. S., 1970. Accumulation rates of manganese in pelagic sediments and nodules. Earth Planet. Sci. Lett., 8:143-148.

Berggren, W. A., 1973. Pliocene time scale: Calibration of planktonic foraminiferal and cretaceous nannoplankton zones. Nature, 243:391-397.

Bezrukov, P. L., and Romankevich, E. A., 1970. Rate of sedimentation in the Pacific Ocean. In Bezrukov, P. L. (Ed.-in-Chief), Sedimentation in the Pacific Ocean (Vol. 2): Moscow (Nauka), 288-300.

Bogdanov, Y. A., and Chekhovskich, E. M., 1979. Rates of sedimentation and absolute masses. In Smirnov, V. I. (Ed.-in-Chief), Metalliferous Sediments of the South-Eastern Pacific Ocean: Moscow (Nauka), 110-121.

Boltovskoy, E., 1980. The age of the Drake Passage. Alcheringa, 4 (no. 3-4):289-297.

Bostrom, K., Kraemer, T., and Gartner, S., 1973. Provenance and accumulation rates of opaline silica, $\mathrm{Al}, \mathrm{Ti}, \mathrm{Fe}, \mathrm{Mn}, \mathrm{Cu}, \mathrm{Ni}$ and $\mathrm{Co}$ in Pacific pelagic sediments. Chem. Geol., 11:123-148.

Chester, R., 1965. Elemental geochemistry of marine sediments. In Riley, J. P., and Skirrow, G. (Eds.), Chemical Oceanography: London (Academic Press), pp. 23-80.

Chester, R., and Aston, S. A., 1976. The geochemistry of deep-sea sediments. In Riley, J. P., and Chester, R. (Eds.), Chemical Oceanography (Vol. 6): London (Academic Press), 281-390.

Ciesielski, P., and Wise, S. W., 1977. Geologic history of the Maurice Ewing Bank of the Falkland Plateau (South Atlantic Sector of the Southern Ocean) based on piston and drill cores. Mar. Geol., 25:175-207.

Davis, J. C., 1973. Statistics and Data Analysis in Geology: New York (John Wiley and Sons).

Geological Society of London, 1964. Phanerozoic time scale. Geol. Soc. London, Quat. J., 120:260-262.

Goldberg, E. D., and Arrhenius, G. O. S., 1958. Chemistry of Pacific pelagic sediments. Geochim. Cosmochim. Acta, 13:153-212.

Gurvich, E. G., Bogdanov, Y. A., and Lisitzin, A. P., 1978. Barium behavior in recent sedimentation in the Pacific Ocean. Geokhimia, 3:359-374.

Hardenbol, J., and Berggren, W. A., 1978. A new Paleogene numerical time scale. Am. Assoc. Pet. Geol., Stud. Geol., 6:213-234.

Herman, H. H., 1967. Modern Factor Analysis: Chicago (University of Chicago Press).

Kennett, J., and Shackleton, N., 1976. Oxygen isotopic evidence for the development of the psychosphere 38 m.y. ago. Nature, 260: 513-515.

Larson, R. L., and Hilde, T. W. C., 1975. A reversal time scale of magnetic reversals for the Early Cretaceous and Late Jurassic. $J$. Geophys. Res., 80:2586-2594.

Leinen, M., and Stakes, D., 1979. Metal accumulation rates in the Central Equatorial Pacific during Cenozoic time. Geol. Soc. Am. Bull., Pt. 1, 90:357-375.

Lisitzin, A. P., 1978. Processes of Oceanic Sedimentation: Lithology and Geochemistry: Moscow (Nauka).

Loutit, T. S., and Kennett, J. P., 1981. Australian Cenozoic sedimentary cycles, global sea level changes and the deep sea sedimentary records. Oceanol. Acta, Proc. 26th Int. Geol. Cong., Paris, Geol. Cont. Margins Symp., pp. 45-63.

Ludwig, W. J., Krasheninnikov, V. A., Basov, I. A, Bayer, U., Bloemendal, J., Bornhold, B., Ciesielski, P,. Goldstein, E. H., Robert C., Usher, J. L., Salloway, J. C., von der Dick, H., Weaver, F. M., and Wise, S. W., 1980. Tertiary and Cretaceous paleoenvironments in the southern Atlantic Ocean: Preliminary results of Deep Sea Drilling Project Leg 71. Geol. Soc. Am. Bull., Pt. 1, 91: 655-664. 
Lyle, M., 1976. Estimation of hydrochemical manganese input to the oceans. Geology, 4:733-736.

McArthur, J. M., and Elderfield, H., 1977. Metal accumulation rates in sediments from Mid-Indian Ocean Ridge and Marie Celeste Fracture Zone. Nature, 266:437-439.

McCoy, F. W., and Zimmerman, M. B., 1977. A history of sediment lithofacies in the South Atlantic Ocean. In Supko, P. R., PerchNielsen, K., Init. Repts. DSDP, 39: Washington (U.S. Govt. Printing Office), 1047-1079.

Martin, J. H., and Knauer, G. A., 1973. The elemental composition of plankton. Geochim. Cosmochim. Acta, 37:1639-1653.

Shipboard Scientific Party, Harris, W., and Sliter, W. V., 1977. Evolution of the Southwestern Atlantic Ocean basin: Results of Leg 36, Deep Sea Drilling Project. In Barker, P. F., Dalziel, I. W. D., et al., Init. Repts. DSDP, 36: Washington (U.S. Govt. Printing Office), 993-1014.

Tarney, J., and Donnellan, N. C. B., 1977. Minor element geochemistry of sediments at Site 328, Falkland Outer Basin and Site 329, Falkland Plateau, Leg 36, Deep Sea Drilling Project. In Barker, P. F., Dalziel, I. W. D., et al., Init. Repts. DSDP, 36: Washington (U.S. Govt. Printing Office), 929-939.

Thiede, J., 1981. Late Mesozoic and Cenozoic sedimentation along oceanic island margins: analog to continental margins. Oceanol. Acta, Proc. 26th Int. Geol. Cong. Paris, Geol. Cont. Margins Symp., pp. 65-70.

Thiede, J., and van Andel, Tj. H., 1977. The paleoenvironments of anaerobic sediments in the late Mesozoic South Atlantic Ocean. Earth Planet. Sci. Lett., 33:301-309.
Thompson, R. W., 1977. Mesozoic sedimentation on the eastern Falkland Plateau. In Barker, P. F., Dalziel, I. W. D., et al., Init. Repts. DSDP, 36: Washington (U.S. Govt. Printing Office), 877-891.

Turekian, K. K., and Wedepohl, K. H., 1961. Distribution of the elements in some major units of the Earth's crust. Geol. Soc. Am. Bull., 72:175-192.

Van Eysinga, F. W. B., 1975. Geological Time Table (3rd ed.): Am sterdam (Elsevier).

von Bennekom, A. J., and van der Gaast S. J., 1976. Possible clay structures in frustules of living diatoms. Geochim. Cosmochim. Acta, 40:1149-1152.

Varentsov, I. M., 1978. The geochemistry of heavy metals in Upper Cenozoic sediments near the crest of the Mid-Atlantic Ridge, latitude $23^{\circ} \mathrm{N}$, drilled on DSDP Leg 45. In Melson, W. G., Rabinowitz, P. D., et al., Init. Repts. DSDP, 45: Washington (U.S. Govt. Printing Office), 349-377.

1980. Metalliferous sediments of the North Atlantic (geochemistry, peculiar features of their formation). Marine Geology, Sedimentology, Sedimentary Petrography and Geology of the Oceans. (International Geological Congress, 26th Session, Reports of Soviet Geologists): Leningrad (Nedra), pp. 29-42.

Varentsov, I. M., Timofeev, P. P., and Rateev, M. A., 1981. Geochemical history of post-Jurassic sedimentation in the Central Northwestern Pacific, western Mid-Pacific Mountains, Deep Sea Drilling Project, Site 463. In Thiede, J., Vallier T. L., et al., Init. Repts. DSDP, 62: Washington (U.S. Govt. Printing Office), 785-804. 
APPENDIX A

Average Chemical Composition of Post-Jurassic Sediments DSDP Leg 71, Sites 511-513

Component (wt.\% air-dry)

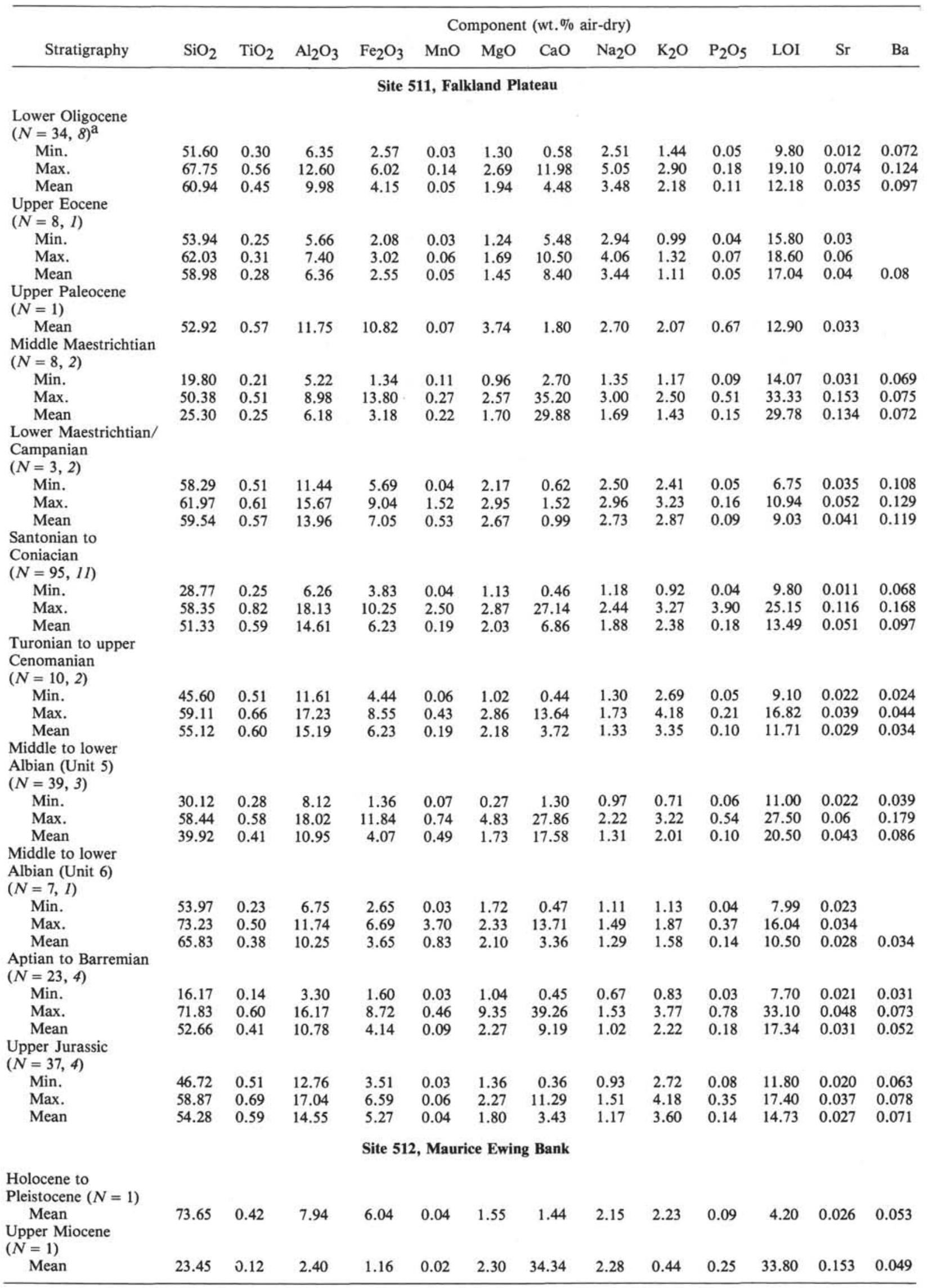


Appendix A. (Continued).

\begin{tabular}{|c|c|c|c|c|c|c|c|c|c|c|c|c|c|}
\hline \multirow[b]{2}{*}{ Stratigraphy } & \multicolumn{13}{|c|}{ Component (wt. \% air-dry) } \\
\hline & $\mathrm{SiO}_{2}$ & $\mathrm{TiO}_{2}$ & $\mathrm{Al}_{2} \mathrm{O}_{3}$ & $\mathrm{Fe}_{2} \mathrm{O}_{3}$ & $\mathrm{MnO}$ & $\mathrm{MgO}$ & $\mathrm{CaO}$ & $\mathrm{Na}_{2} \mathrm{O}$ & $\mathrm{K}_{2} \mathrm{O}$ & $\mathrm{P}_{2} \mathrm{O}_{5}$ & LOI & $\mathrm{Sr}$ & $\mathrm{Ba}$ \\
\hline \multicolumn{14}{|l|}{$\begin{array}{l}\text { Middle Miocene } \\
(N=8)\end{array}$} \\
\hline Min. & 19.60 & 0.09 & 1.83 & 1.13 & 0.02 & 1.60 & 8.94 & 1.73 & 0.35 & 0.06 & 16.80 & 0.055 & 0.015 \\
\hline Max. & 57.78 & 0.31 & 6.12 & 2.43 & 0.03 & 2.30 & 40.07 & 3.87 & 1.15 & 0.09 & 31.80 & 0.186 & 0.162 \\
\hline Mean & 41.16 & 0.18 & 3.66 & 1.81 & 0.02 & 1.96 & 22.76 & 2.70 & 0.72 & 0.07 & 24.80 & 0.114 & 0.071 \\
\hline \multicolumn{14}{|l|}{$\begin{array}{l}\text { Middle Eocene } \\
(N=43)\end{array}$} \\
\hline Min. & 14.30 & 0.13 & 3.10 & 1.47 & 0.03 & 1.49 & 22.84 & 1.19 & 0.46 & 0.09 & 21.40 & 0.096 & 0.085 \\
\hline Max. & 36.75 & 0.32 & 8.50 & 3.32 & 0.06 & 2.78 & 40.00 & 2.77 & 1.69 & 0.76 & 36.60 & 0.910 & 0.163 \\
\hline Mean & 23.63 & 0.21 & 4.63 & 2.01 & 0.05 & 2.28 & 32.50 & 1.84 & 0.73 & 0.13 & 31.95 & 0.162 & 0.111 \\
\hline \multicolumn{14}{|c|}{ Site 513, Eastern Argentine Basin } \\
\hline \multirow{2}{*}{\multicolumn{14}{|c|}{$\begin{array}{l}\text { Holocene to } \\
\text { Pleistocene } \\
(N=10)\end{array}$}} \\
\hline & & & & & & & & & & & & & \\
\hline Min. & 64.65 & 0.25 & 5.60 & 2.56 & 0.03 & 1.36 & 0.63 & 2.95 & 1.16 & 0.03 & 9.54 & 0.008 & 0.069 \\
\hline Max. & 72.80 & 0.48 & 9.97 & 3.66 & 0.06 & 2.12 & 1.24 & 5.62 & 1.92 & 0.07 & 13.74 & 0.021 & 0.12 \\
\hline Mean & 67.42 & 0.40 & 8.44 & 3.48 & 0.04 & 1.85 & 1.00 & 4.19 & 1.69 & 0.05 & 11.22 & 0.016 & 0.090 \\
\hline \multicolumn{14}{|l|}{$\begin{array}{l}\text { Upper Pliocene } \\
(N=18)\end{array}$} \\
\hline Min. & 62.64 & 0.38 & 7.84 & 3.03 & 0.04 & 1.67 & 1.03 & 3.45 & 1.57 & 0.05 & 9.42 & 0.015 & 0.065 \\
\hline Max. & 69.35 & 0.60 & 12.48 & 5.69 & 0.06 & 2.29 & 1.51 & 4.03 & 2.39 & 0.07 & 11.36 & 0.030 & 0.125 \\
\hline Mean & 65.63 & 0.48 & 9.79 & 4.36 & 0.05 & 1.99 & 1.19 & 3.77 & 1.98 & 0.06 & 10.53 & 0.020 & 0.100 \\
\hline \multicolumn{14}{|c|}{$\begin{array}{l}\text { Lower Pliocene (U-1) } \\
(N=30)\end{array}$} \\
\hline Min. & 58.33 & 0.40 & 8.57 & 4.39 & 0.04 & 1.74 & 0.88 & 3.11 & 1.73 & 0.04 & 9.40 & 0.018 & 0.012 \\
\hline Max. & 66.30 & 0.68 & 13.83 & 6.89 & 0.10 & 2.67 & 1.48 & 4.50 & 2.80 & 0.10 & 12.70 & 0.029 & 0.135 \\
\hline Mean & 61.96 & 0.58 & 11.93 & 5.27 & 0.06 & 2.17 & 1.19 & 3.76 & 2.36 & 0.06 & 10.54 & 0.025 & 0.107 \\
\hline \multicolumn{14}{|c|}{$\begin{array}{l}\text { Upper Miocene (U-1) } \\
(N=36)\end{array}$} \\
\hline Min. & 56.97 & 0.51 & 10.81 & 4.55 & 0.05 & 1.95 & 1.00 & 2.98 & 2.04 & 0.05 & 9.30 & 0.021 & 0.087 \\
\hline Max. & 64.30 & 0.68 & 13.61 & 8.75 & 0.11 & 2.78 & 1.56 & 4.27 & 2.67 & 0.13 & 11.80 & 0.041 & 0.143 \\
\hline Mean & 60.68 & 0.60 & 12.24 & 5.64 & 0.07 & 2.32 & 1.27 & 3.70 & 2.36 & 0.07 & 10.97 & 0.029 & 0.115 \\
\hline \multicolumn{14}{|l|}{$\begin{array}{l}\text { Lower Miocene } \\
(\mathrm{U}-2 \mathrm{~A})(N=4)\end{array}$} \\
\hline Min. & 54.10 & 0.61 & 13.03 & 5.63 & 0.08 & 2.59 & 1.39 & 3.21 & 2.31 & 0.08 & 10.30 & 0.030 & 0.145 \\
\hline Max. & 56.90 & 0.73 & 14.38 & 7.49 & 0.12 & 3.10 & 1.84 & 4.71 & 2.67 & 0.34 & 13.70 & 0.033 & 0.206 \\
\hline Mean & 55.32 & 0.64 & 13.55 & 6.21 & 0.11 & 2.84 & 1.66 & 4.32 & 2.43 & 0.25 & 12.64 & 0.031 & 0.183 \\
\hline \multicolumn{14}{|l|}{$\begin{array}{l}\text { Lower Miocene } \\
(\mathrm{U}-2 \mathrm{~A})(N=10)\end{array}$} \\
\hline Min. & 30.04 & 0.21 & 4.43 & 1.91 & 0.11 & 1.49 & 16.40 & 2.31 & 1.00 & 0.08 & 21.40 & 0.098 & 0.07 \\
\hline Max. & 43.37 & 0.33 & 7.51 & 4.07 & 0.17 & 1.97 & 28.68 & 3.72 & 1.52 & 0.16 & 29.70 & 0.148 & 0.14 \\
\hline Mean & 34.61 & 0.28 & 5.83 & 2.66 & 0.13 & 1.72 & 23.86 & 2.72 & 1.26 & 0.11 & 26.68 & 0.125 & 0.095 \\
\hline \multicolumn{14}{|l|}{$\begin{array}{l}\text { Oligocene (U-2A) } \\
(N=9)\end{array}$} \\
\hline Min. & 51.55 & 0.28 & 6.23 & 2.82 & 0.06 & 1.52 & 0.97 & 3.02 & 1.36 & 0.11 & 13.20 & 0.023 & 0.113 \\
\hline Max. & 64.31 & 0.48 & 9.65 & 4.24 & 0.08 & 2.40 & 10.63 & 4.00 & 2.09 & 0.17 & 19.29 & 0.077 & 0.23 \\
\hline Mean & 58.82 & 0.38 & 8.09 & 3.45 & 0.07 & 1.94 & 5.85 & 3.37 & 1.75 & 0.13 & 15.93 & 0.047 & 0.172 \\
\hline \multicolumn{14}{|l|}{$\begin{array}{l}\text { Oligocene (U-2B) } \\
(N=6)\end{array}$} \\
\hline Min. & 16.47 & 0.14 & 2.93 & 1.39 & 0.09 & 1.42 & 12.36 & 1.67 & 0.66 & 0.06 & 19.10 & 0.073 & 0.015 \\
\hline Max. & 51.06 & 0.35 & 7.20 & 3.08 & 0.12 & 2.24 & 39.00 & 2.45 & 1.70 & 0.11 & 35.20 & 0.170 & 0.15 \\
\hline Mean & 30.52 & 0.20 & 4.14 & 1.83 & 0.11 & 1.79 & 26.55 & 2.18 & 0.99 & 0.07 & 29.62 & 0.131 & 0.069 \\
\hline \multicolumn{14}{|l|}{$\begin{array}{l}\text { Oligocene (U-3A) } \\
(N=38)\end{array}$} \\
\hline Min. & 6.69 & 0.04 & 1.12 & 0.79 & 0.05 & 1.07 & 23.23 & 1.05 & 0.32 & 0.03 & 26.00 & 0.098 & 0.015 \\
\hline Max. & 39.13 & 0.33 & 6.55 & 8.81 & 0.14 & 2.44 & 45.11 & 2.80 & 1.61 & 0.15 & 38.60 & 0.18 & 0.165 \\
\hline Mean & 26.74 & 0.14 & 2.91 & 1.72 & 0.08 & 1.68 & 32.69 & 1.61 & 0.77 & 0.08 & 31.40 & 0.129 & 0.089 \\
\hline
\end{tabular}

${ }^{\mathrm{a}} \mathrm{N}$ for $\mathrm{Ba}$ in italics. 


\section{M. VARENTSOV}

APPENDIX B

Chemical Composition of Cenozoic Sediments in the Eastern Region of the Argentine Basin, Southwestern Atlantic, DSDP Leg 71, Site 514

\begin{tabular}{|c|c|c|c|c|c|c|c|c|c|c|c|c|c|c|c|c|c|c|c|c|c|c|c|c|}
\hline \multicolumn{25}{|c|}{ Component (wt.\% air-dry) } \\
\hline Stratigraphy & $\mathrm{Na}_{2} \mathrm{O}$ & $\mathrm{MgO}$ & $\mathrm{Al}_{2} \mathrm{O}_{3}$ & $\mathrm{SiO}_{2}$ & $\mathrm{P}_{2} \mathrm{O}_{5}$ & $\mathrm{~K}_{2} \mathrm{O}$ & $\mathrm{CaO}$ & $\mathrm{TiO}_{2}$ & $\mathrm{MnO}$ & $\mathrm{Fe}_{2} \mathrm{O}_{3}$ & LOI & St & $\mathrm{Ba}$ & Al & K & $\mathrm{Ti}$ & Mn & $\mathrm{Fe}$ & $\mathbf{P}$ & $\mathrm{K} / \mathrm{Al}$ & $\mathrm{Mn} / \mathrm{Fe}$ & $\mathrm{T} / \mathrm{Al}$ & $\mathrm{Ba} / \mathrm{Al}$ & $\mathrm{Sr} / \mathrm{Al}$ \\
\hline \multicolumn{25}{|l|}{$\begin{array}{l}\text { Holocene- } \\
\text { Pleistocene } \\
(N=14)\end{array}$} \\
\hline Min. & 3.38 & 2.14 & 10.92 & 58.09 & 0.07 & 2.21 & 1.06 & 0.54 & 0.05 & 4.34 & 9.80 & 0.018 & 0.069 & 5.78 & 1.87 & 0.32 & 0.04 & 3.03 & 0.03 & & & & & \\
\hline Max. & 5.06 & 2.74 & 14.18 & 63.01 & 0.10 & 2.66 & 3.34 & 0.71 & 0.22 & 5.98 & 12.50 & 0.032 & 0.149 & 7.50 & 2.26 & 0.43 & 0.17 & 4.18 & 0.04 & & & & & \\
\hline Mean & 3.98 & 2.45 & 12.17 & 60.92 & 0.08 & 2.38 & 1.37 & 0.61 & 0.07 & 5.16 & 10.72 & 0.024 & 0.102 & 6.44 & 2.02 & 0.36 & 0.06 & 3.61 & 0.03 & 0.314 & 0.017 & 0.056 & 0.016 & 0.004 \\
\hline $\begin{array}{l}\text { Pliocene (U-1A) } \\
(N=69)\end{array}$ & & & & & & & & & & & & & & & & & & & & & & & & \\
\hline Min. & 2.95 & 1.63 & 7.74 & 57.26 & 0.05 & 1.52 & 0.88 & 0.38 & 0.04 & 3.76 & 10.00 & 0.018 & 0.073 & 4.09 & 1.29 & 0.23 & 0.03 & 2.63 & 0.02 & & & & & \\
\hline Max. & 4.84 & 2.97 & 14.51 & 65.12 & 0.10 & 2.78 & 2.17 & 0.72 & 0.17 & 6.96 & 13.90 & 0.032 & 0.179 & 7.68 & 2.36 & 0.43 & 0.13 & 4.87 & 0.04 & & & & & \\
\hline Mean & 3.75 & 2.43 & 11.85 & 61.03 & 0.07 & 2.36 & 1.21 & 0.58 & 0.07 & 5.23 & 11.32 & 0.025 & 0.116 & 6.27 & 2.00 & 0.35 & 0.06 & 3.66 & 0.03 & 0.319 & 0.016 & 0.056 & 0.019 & 0.004 \\
\hline \multicolumn{25}{|l|}{$\begin{array}{l}\text { Pliocene (U-1B) } \\
(N=5)\end{array}$} \\
\hline Min. & 3.03 & 2.49 & 12.13 & 57.32 & 0.06 & 2.30 & 1.07 & 0.61 & 0.06 & 5.09 & 9.40 & 0.026 & 0.119 & 6.42 & 1.95 & 0.35 & 0.05 & 3.56 & 0.03 & & & & & \\
\hline Max. & 4.34 & 2.97 & 14.98 & 60.82 & 0.10 & 2.79 & 2.99 & 0.73 & 0.09 & 6.09 & 12.60 & 0.032 & 0.169 & 7.92 & 2.37 & 0.44 & 0.07 & 4.26 & 0.04 & & & & & \\
\hline Mean & 3.34 & 2.66 & 13.37 & 58.56 & 0.08 & 2.57 & 1.83 & 0.65 & 0.08 & 5.69 & 11.24 & 0.029 & 0.145 & 7.07 & 2.18 & 0.39 & 0.06 & 3.98 & 0.03 & 0.308 & 0.015 & 0.055 & 0.021 & 0.004 \\
\hline \multicolumn{25}{|l|}{$\begin{array}{l}\text { Pliocene (U-1C) } \\
(N=9)\end{array}$} \\
\hline Min. & 2.85 & 2.18 & 8.03 & 42.57 & 0.06 & 1.43 & 0.92 & 0.43 & 0.05 & 3.75 & 10.70 & 0.021 & 0.11 & 4.25 & 1.21 & 0.26 & 0.04 & 2.62 & 0.03 & & & & & \\
\hline Max. & 3.51 & 2.42 & 13.00 & 63.00 & 0.17 & 2.44 & 15.80 & 0.69 & 0.80 & 5.87 & 21.50 & 0.034 & 0.155 & 6.88 & 2.07 & 0.41 & 0.62 & 4.10 & 0.07 & & & & & \\
\hline Mean & 3.23 & 2.31 & 11.63 & 59.06 & 0.08 & 2.19 & 2.96 & 0.61 & 0.15 & 5.05 & 12.58 & 0.027 & 0.134 & 6.16 & 1.86 & 0.36 & 0.11 & 3.53 & 0.04 & 0,302 & 0.031 & 0.058 & 0.022 & 0.004 \\
\hline
\end{tabular}

